\title{
Petrogenesis of Tin-bearing Granites from Ervedosa, Northern Portugal: The Importance of Magmatic Processes
}

\author{
M. E. P. Gomes ${ }^{1, *}$ and A. M. R. Neiva ${ }^{2}$ \\ ${ }^{1}$ Department of Geology, University of Trás-os-Montes and Alto Douro, Portugal \\ ${ }^{2}$ Department of Earth Sciences, University of Coimbra, Portugal
}

Received: 25. 8. 2001 - Accepted: 17. 1. 2001

\begin{abstract}
Three Hercynian highly peraluminous tin-bearing granites define a sequence ranging from muscovite-biotite granite to muscovite granite. Tin-bearing quartz veins are genetically related to this sequence. Variation diagrams of most major and trace elements of granites, biotite and muscovite show fractionation trends. Least squares analysis of major elements and modelling of trace elements indicate that the muscovite-biotite granite M2 and the muscovite granite M3 were derived from the slightly porphyritic muscovite-biotite granite magma M1 by fractional crystallization of plagioclase, Kfeldspar, biotite and quartz. The granite magma M1 was originated by partial fusion of peraluminous metasedimentary crustal materials. The magmatic fractionation was responsible for the increase in Sn contents of granites and their micas. Biotite has higher Sn content than coexisting muscovite. However, muscovite retains a higher percentage of the total granite Sn content, up to $99 \%$ of the muscovite granite. The very rare magmatic cassiterite present in muscovite granite $\mathrm{M} 3$ confirms the tin enrichment of magma. In the sequence, the melt temperature decreases from 765 to $735{ }^{\circ} \mathrm{C}, \mathrm{P}_{\mathrm{H}_{2} \mathrm{O}}$ decreases from 4 to $3 \mathrm{~kb}$, and the $\mathrm{F}$ content in melt increases. Feldspars reequilibrated at $567-329^{\circ} \mathrm{C}$.
\end{abstract}

Key words: tin-bearing granites, magmatic fractionation, micas, northern Portugal, cassiterite

\section{* Corresponding address:}

M. E. P. Gomes, Department of Geology, University of Trás-os-Montes and Alto Douro, 5001 Vila Real, Portugal

Tel.: ++351-259-350261; Fax: ++351-259-350480; e-mail: mgomes@utad.pt 


\section{Introduction}

The Sn deposits related to granitic rocks may be the result of magmatic and hydrothermal processes (e.g. Lehmann 1982, 1990; Neiva 1984). Experimental studies of crystallization of volatile-enriched magmas, the volcanic analogues of rare-metal granites and the petrology of granitic rocks associated to some Sn deposits have revealed the importance of magmatic fractionation processes (Lehmann 1990; Pichavant 1997).

The tin-bearing quartz veins from Ervedosa, Bragança region (northern Portugal), were exploited for tin. The ore deposit was identified in 1908. Between 1909 and 1927, the mine exploitation was irregular. From 1928 until 1969, the continuous exploitation of the Ervedosa mine, also known as the Tuela mine, was carried out by Tuela Tin Mines Ldt., producing about 6000 tons of tin and a similar weight of $\mathrm{As}_{2} \mathrm{O}_{3}$. The exploitation started underground and continued at two large open pits. Close to the end, alluvial placers were also exploited. The exploitation ended due to the low cassiterite concentrations, from 0.8 to $2 \mathrm{~kg} /$ ton (Casminex report 1982). They are spatially associated with a muscovite granite and genetically related to the tin-bearing granites sequence (Gomes 1996).

This paper presents the geology, mineralogy, petrology and geochemistry of three tin-bearing granites and their minerals from Ervedosa in order to understand their petrogenesis and the origin of high concentrations of tin in granites and their micas. The whole-rock geochemical data and chemical compositions of minerals were used to test specific involved magmatic processes and to show the importance of magmatic fractionation in the Sn enrichment in late-stage granites. The main conclusions on a Hercynian peraluminous granite suite in northern Portugal are important for understanding the behaviour of tin during granite magma differentiation.

\section{Geological setting}

The Ervedosa area (Fig. 1) lies in the Galiza and Trás-os-Montes Zone within the imbricated margins of the Iberian Terrane (Ribeiro et. al. 1990). It belongs to the lower Silurian so-called "Peritransmontain Subdomain" of the parautochthonous domain defined by Ribeiro (1974). At Ervedosa this subdomain consists mainly of mica schists and quartzites (Lécolle et al. 1981), which are deformed by three tectonic deformation phases D1, D2 and D3 (Ribeiro 1974). They have a low degree of regional metamorphism with a maximum temperature $450{ }^{\circ} \mathrm{C}$ and pressure 6-7 $\mathrm{kb}$ (Lécolle et al. 1981).

Three peraluminous Hercynian granites M1, M2 and M3 define a whole-rock Rb-Sr isochron which yields an age of $327 \pm 9 \mathrm{Ma}$ (Gomes 1996), and intruded Silurian metasedimentary rocks, which include carbon-rich metasediments, in the core of an antiform D2-D3 and a medium- to coarse-grained porphyritic biotite-muscovite granite $(357 \pm 9 \mathrm{Ma}$; Gomes 1996) showing sharp contacts. The medium- to coarse-grained porphyritic muscovite-biotite granite (319 $\pm 7 \mathrm{Ma}$; Gomes 1996) surrounds the oldest biotite-muscovite granite and the granites M1 and M2, with contacts that are also sharp. The oldest biotite-muscovite granite and the youngest muscovite-biotite granite do not show any relationship with the granites M1, M2 and M3 that are presented in this paper. The granites M1, M2 and M3 contain rare small "hipermicaceous" enclaves up to $4 \times 5$ $\mathrm{cm}$ and hornfels enclaves up to $10 \times 5 \mathrm{~cm}$ in dimension. 


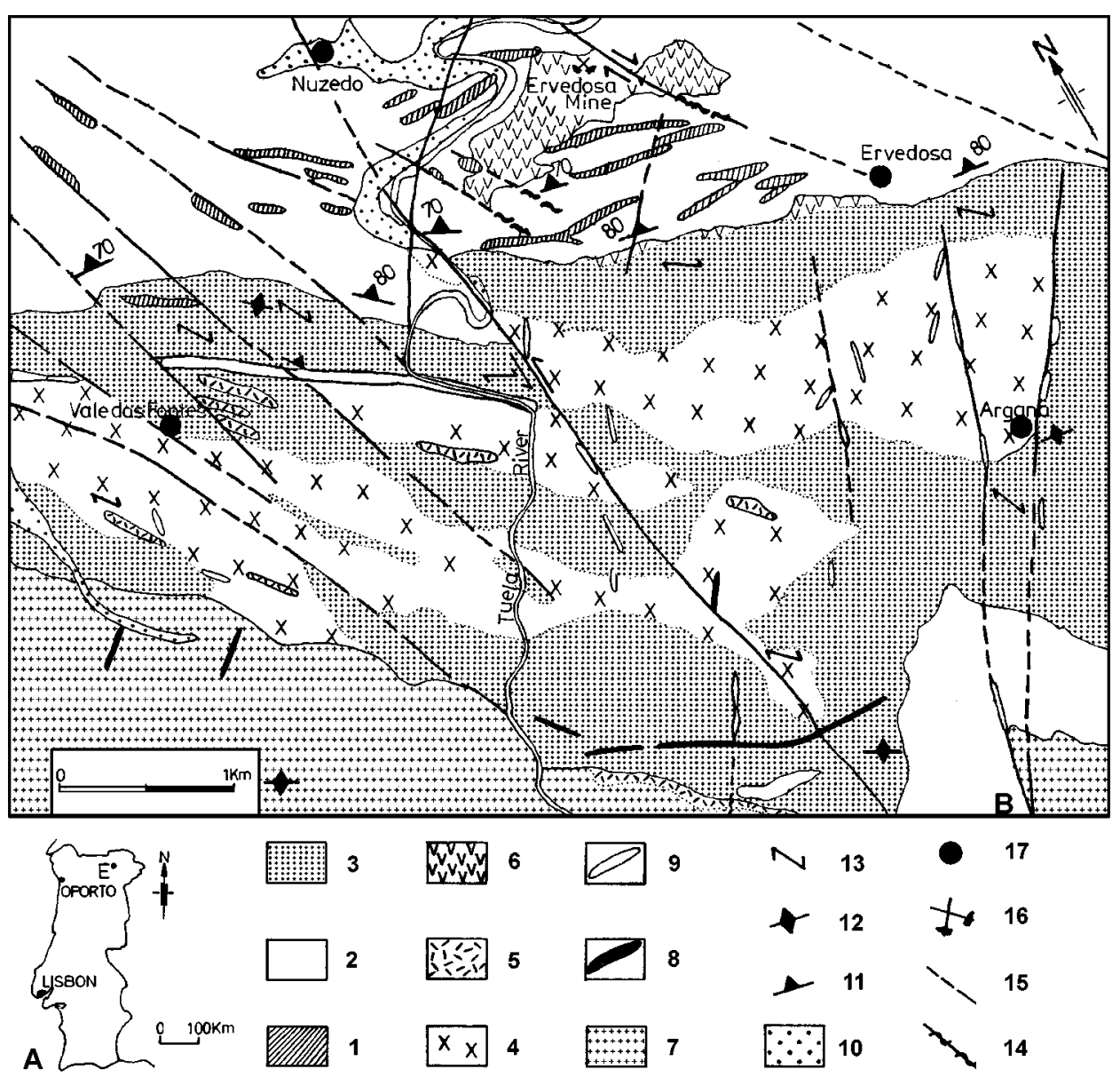

Fig. 1. a) Location of the Ervedosa area on the map of Portugal; b) Geological map of the Ervedosa area. 1 - Silurian mica schists 2 - Silurian quartzites, 3 - medium- to coarse-grained porphyritic biotitemuscovite granite, 4 - medium-grained slightly porphyritic muscovite-biotite granite (M1), 5 medium- to fine-grained muscovite-biotite granite (M2), 6 - fine- to medium-grained muscovite granite (M3), 7 - medium- to coarse-grained porphyritic muscovite-biotite granite, 8 - aplite and pegmatite veins, 9 - quartz veins, 10 - alluvial deposits, 11 - strike and dip of main schistosity, 12 - foliation, 13 - C planes, 14 - shear zone, 15 - fault and probable fault, 16 - closed tin mine, 17 - village.

The medium-grained slightly porphyritic muscovite-biotite granite (M1) has C-S strutures, generally $\mathrm{N} 20^{\circ} \mathrm{W}$ to $\mathrm{C}$ planes and $\mathrm{N} 55^{\circ} \mathrm{W}$ to $\mathrm{S}$ planes. It contains rare microgranular enclaves up to $20 \times 10 \mathrm{~cm}$ in dimension showing the same deformation. Locally, M1 passes gradually to the medium- to fine-grained muscovite-biotite granite (M2) which has a clear foliation $\mathrm{N} 50-55^{\circ} \mathrm{W}$.

The fine- to medium-grained muscovite granite (M3) intruded the metasedimentary rocks in the northeast part of the area, forming an E-W elongated body that shows a sharp contact. It has a foliation $\mathrm{N} 55-60^{\circ} \mathrm{W}$ and was affected by a dextral $\mathrm{N} 30^{\circ} \mathrm{W}$ shear zone. Muscovite granite also crops out between the contact of the biotite-muscovite granite 
with the country rocks and occurs in small elongated outcrops cutting this granite; the contacts are sharp. M3 produced a mica schist of contact metamorphism with a thickness of about $1 \mathrm{~m}$, containing quartz, muscovite, chlorite, biotite, albite and opaque minerals.

The granites M1 and M2 are cut by aplite and pegmatites veins, $2 \mathrm{~m}$ thick, orientated NE-SW to ENE-WSW and showing S-C deformation similar to that of the respective granite they cut.

N-S and NNE-SSW faults later than D3 were penetrated by quartz veins and cut Silurian mica-schists and the Hercynian granites. In some of them, particularly in the Ervedosa mine, Sn was exploited. The stanniferous quartz veins are spatially linked to the granite M3 and they fill faults related to the movements along the ductil shear zone (Gomes 1996).

\section{Petrography}

All the granites contain quartz, K-feldspar, plagioclase, muscovite, biotite, rare chlorite, monazite, apatite, zircon, ilmenite, rutile and uraninite. The granites have a subhedral granular texture. The main petrographic characteristics of the tin-bearing granites are given in Table 1. Following the classification of Le Bas and Streckeisen (1991), M1 belongs to the monzogranite family, while M2 and M3 are alkali granites.

Quartz is anhedral with undulatory extinction. It contains inclusions of the other minerals. Quartz eyes (Candela 1997) surrounded by muscovite were found in M3 (Fig. 2a), whose quartz grains are very fractured and broken close to the shear zone.

K-feldspar and plagioclase are generally subhedral to anhedral. All granites have phenocrysts of K-feldspar and M1 also has phenocrysts of plagioclase, polysynthetically twinned. Phenocrysts have rounded and smooth margins. They contain inclusions of biotite, muscovite, quartz and apatite. In M1, later K-feldspar and albite were found in shear bands (Fig. 2b) and later K-feldspar also occurs along biotite and chlorite cleavages.

Biotite and muscovite are subhedral and intergrown (Fig. 2c). They contain inclusions of quartz, sillimanite, zircon, apatite, monazite, ilmenite and rutile. Muscovite textures are similar to those of primary muscovite (P) of Miller et al. (1981) and Monier et al. (1984). In M1, some biotite and muscovite are anhedral; they frequently contain inclu-

Table 1. Petrographic characteristics of tin-bearing granites from Ervedosa.

\begin{tabular}{|c|c|c|c|}
\hline & M1 & M2 & M3 \\
\hline Muscovite $\%$ & $3.5-7.4$ & $9.2-10.9$ & $11.6-15.4$ \\
\hline Biotite $\%$ & $2.4-4.7$ & $0.9-1.3$ & $0.0-0.7$ \\
\hline Phenocrysts & $\begin{array}{l}\text { Rare of K-feldspar } \\
\text { and oligoclase }\end{array}$ & K-feldspar & $\begin{array}{l}\text { Very rare of } \\
\text { microcline }\end{array}$ \\
\hline $\begin{array}{l}\text { Biotite } \\
\text { pleochroism }\end{array}$ & $\begin{array}{l}\beta=\gamma=\text { reddish brown } \\
\alpha=\text { pale vellow }\end{array}$ & $\begin{array}{l}\beta=\gamma=\text { reddish brown } \\
\alpha=\text { pale vellow }\end{array}$ & $\begin{array}{l}\beta=\gamma=\text { reddish brown, } \\
\alpha=\text { pale vellow }\end{array}$ \\
\hline $\begin{array}{l}\text { Accessory } \\
\text { minerals }\end{array}$ & $\begin{array}{l}\text { tourmaline, andalusite, } \\
\text { sillimanite, ilmenite, } \\
\text { zircon, monazite, apatite }\end{array}$ & $\begin{array}{l}\text { tourmaline, rare } \\
\text { sillimanite, apatite }\end{array}$ & $\begin{array}{l}\text { zircon, ilmenite, } \\
\text { monazite, apatite, } \\
\text { sulphides, uraninite }\end{array}$ \\
\hline
\end{tabular}

M1 - medium-grained slightly porphyritic muscovite-biotite granite, M2 - medium- to fine-grained muscovite-biotite granite, M3 - fine- to medium-grained muscovite granite. 

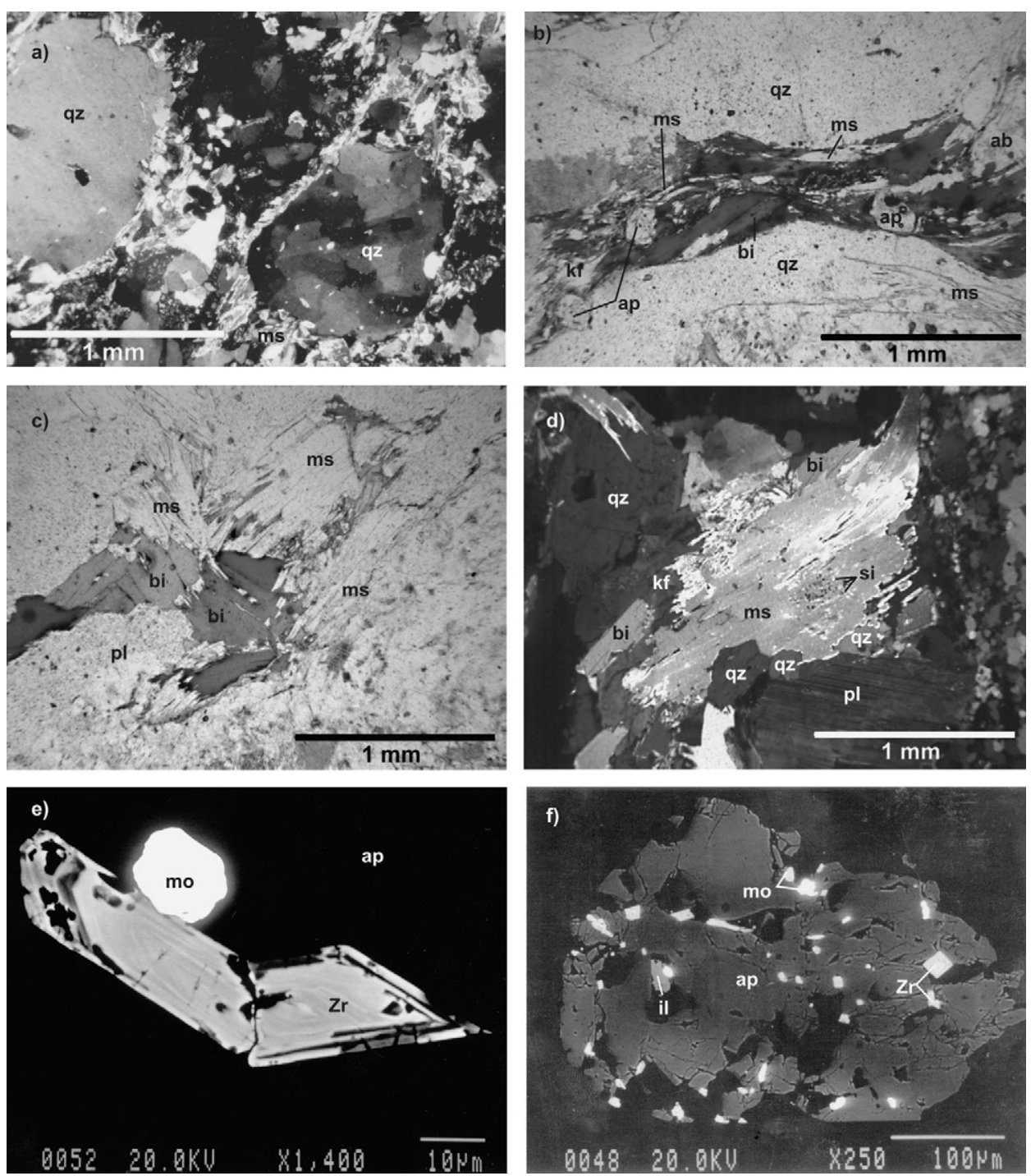

Fig. 2. a), b), c) and d) Photomicrographs from Ervedosa tin-bearing granites: a) Quartz eyes (qz) surrounded by muscovite (ms) in muscovite granite M3 (crossed polarized light); b) Shear band with biotite (bi), muscovite, K-feldspar (Kf), albite (ab), and apatite (ap) in muscovite-biotite granite M1(plane polarized light); c) Biotite and muscovite intergrown in muscovite-biotite granite M2 (plane polarized light); d) Muscovite with inclusions of sillimanite (si) and margins corroded by feldspars and quartz in granite M1(crossed polarized light). e) and f) Backscattered-electron images of accessory minerals from M1: e) complexely zoned and broken zircon (Zr) corroded by monazite (mo); f) Fractured apatite with inclusions of zircon, monazite and ilmenite (il). 
sions of sillimanite, show margins corroded by feldspars and quartz (Fig. 2d) and the flakes are bent. Furthermore, in this granite, there are also later biotite and muscovite with undulatory extinction, in small flakes along the shear bands (Fig. 2b).

Andalusite and sillimanite are interpreted as primary minerals because they have a prismatic habit and are included in micas. They were not found in mutual contact.

Zircon is euhedral, with borders locally corroded by monazite (Fig. 2e). It occurs within feldspars, micas and apatite. Apatite is the most common accessory mineral and occurs mainly as inclusions in micas and rarely in feldspars. Apatite is euhedral or rounded and frequently contains inclusions of zircon, monazite, ilmenite and rutile (Fig. 2f). Other accessory minerals were found (Table 1). Very rare tiny subhedral cassiterite crystals were distinguished, by electron-microprobe, in heavy concentrates of the muscovite granite (M3).

\section{Analytical methods}

The micas were separated with a magnetic separator and heavy liquids. The purity estimated by petrographic examination of the powders is $\sim 99.8 \%$. The main contaminants are monazite and apatite.

The major and trace elements of granites and trace elements of micas were determined by X-ray fluorescence (XRF) at Manchester University, U.K, using the method of Brown et al. (1973), with precisions better than $\pm 1 \%$ for the major elements and $\mathrm{Rb}$ and of $\pm 4 \%$ for the other trace elements. Rare earth elements (REE), Ta, U, Th and Hf of granites were determined by neutron activation with a precision of about $\pm 5 \%$ at the Imperial College Reactor Center, Ascot, U.K.

The major elements of minerals were determined using an electron-microprobe (a Modified Cambridge Geoscan with Link Systems energy-dispersive system) at Manchester University.

Total $\mathrm{Fe}_{2} \mathrm{O}_{3}$ of biotites and $\mathrm{Li}$ of granites and micas were determined by atomic absorption, while $\mathrm{F}$ was determined by selective ion electron analysis; the precision was of about $\pm 2 \%$ for all. $\mathrm{FeO}$ of granites and micas was determined by titration with a standardized potassium permanganate solution; $\mathrm{H}_{2} \mathrm{O}^{+}$was determined using a Penfield tube: both had a precision of about $\pm 1 \%$.

The isotopic studies were carried out at the Department of Earth Sciences, University of Oxford, U.K. Sr was separated by a conventional ion exchange technique (Pankhurst and O'Nions 1973) and isotopically analyzed on single Ta filaments on a VG-Micromass $54 \mathrm{E}$ spectrometer. The ${ }^{87} \mathrm{Sr} /{ }^{86} \mathrm{Sr}$ ratios were corrected for mass-fractionation by normalizing to ${ }^{87} \mathrm{Sr} /{ }^{86} \mathrm{Sr}=0.837521$. The standard used was NBS987, which gave a mean ${ }^{87} \mathrm{Sr} /{ }^{86} \mathrm{Sr}$ of $0.710260 \pm 0.000025$ over the period of work. $2 \sigma$ errors on ${ }^{87} \mathrm{Sr} /{ }^{86} \mathrm{Sr}$ ratios are about $0.007 \%$. Rb/Sr ratios were determined on pressed powder pellets by XRF (Pankhurst and O'Nions 1973). The precision of $\mathrm{Rb} / \mathrm{Sr}$ ratios is about $\pm 2 \%$. $\mathrm{Rb}$ and $\mathrm{Sr}$ contents, computed with absorption coefficients obtained from Compton scatter peak intensities, are precise to better than $\pm 5 \%$. Regression lines were calculated using the least-squares method of York as implemented in the Isoplot program (Ludwig 1990). Errors are quoted at a $95 \%$ confidence level. The Sm-Nd determinations were carried with a VG $54 \mathrm{E}$ mass spectrometer. The uncertainties in ${ }^{147} \mathrm{Sm} /{ }^{144} \mathrm{Nd}$, determined by isotope dilution, were $0.1 \%$. 
Table 2. Average chemical analyses in wt. \%, trace elements and rare earths in ppm of tin-bearing granites from Ervedosa.

\begin{tabular}{|c|c|c|c|c|c|c|}
\hline & M1 & s.d. & M2 & s.d. & M3 & s.d. \\
\hline $\mathrm{SiO}_{2}$ & 72.40 & 0.81 & 73.78 & 0.32 & 74.06 & 0.46 \\
\hline $\mathrm{TiO}_{2}$ & 0.25 & 0.03 & 0.15 & 0.03 & 0.10 & 0.02 \\
\hline $\mathrm{Al}_{2} \mathrm{O}_{3}$ & 14.86 & 0.40 & 14.82 & 0.26 & 14.59 & 0.35 \\
\hline $\mathrm{Fe}_{2} \mathrm{O}_{3}$ & 0.27 & 0.20 & 0.44 & 0.12 & 0.36 & 0.06 \\
\hline $\mathrm{FeO}$ & 1.19 & 0.17 & 0.61 & 0.14 & 0.63 & 0.13 \\
\hline $\mathrm{MnO}$ & 0.10 & 0.01 & 0.10 & 0.01 & 0.10 & 0.01 \\
\hline $\mathrm{MgO}$ & 0.49 & 0.09 & 0.24 & 0.06 & 0.18 & 0.07 \\
\hline $\mathrm{CaO}$ & 0.71 & 0.07 & 0.46 & 0.06 & 0.40 & 0.11 \\
\hline $\mathrm{Na}_{2} \mathrm{O}$ & 3.24 & 0.33 & 3.39 & 0.47 & 3.84 & 0.40 \\
\hline $\mathrm{K}_{2} \mathrm{O}$ & 5.46 & 0.35 & 4.86 & 0.36 & 4.36 & 0.39 \\
\hline $\mathrm{P}_{2} \mathrm{O}_{5}$ & 0.30 & 0.05 & 0.27 & 0.10 & 0.34 & 0.08 \\
\hline $\mathrm{H}_{2} \mathrm{O}^{+}$ & 0.64 & 0.25 & 0.74 & 0.20 & 0.90 & 0.28 \\
\hline $\mathrm{H}_{2}^{-} \mathrm{O}^{-}$ & 0.17 & 0.15 & 0.19 & 0.10 & 0.19 & 0.19 \\
\hline Total & 100.08 & & 100.05 & & 100.05 & \\
\hline $\mathrm{Cl}$ & 306 & 74 & 276 & 58 & 292 & 69 \\
\hline $\mathrm{F}$ & 717 & 79 & 728 & & 1930 & \\
\hline $\mathrm{Cr}$ & 25 & 10 & 12 & 5 & 13 & 5 \\
\hline V & 12 & 4 & * & & 3 & 2 \\
\hline $\mathrm{Nb}$ & 19 & 3 & 19 & 7 & 32 & 6 \\
\hline $\mathrm{Zn}$ & 54 & 9 & 45 & 5 & 103 & 16 \\
\hline Sn & 29 & 10 & 30 & 10 & 72 & 18 \\
\hline $\mathrm{Li}$ & 107 & 36 & 89 & 44 & 190 & 61 \\
\hline $\mathrm{Ni}$ & 9 & 1 & 5 & 2 & 8 & 2 \\
\hline $\mathrm{Zr}$ & 119 & 14 & 70 & 16 & 61 & 6 \\
\hline $\mathrm{Cu}$ & 10 & 5 & 15 & 3 & 71 & 33 \\
\hline $\mathrm{Sc}$ & 8 & 3 & 6 & 1 & $*$ & \\
\hline Y & 46 & 3 & 42 & 3 & 46 & 4 \\
\hline $\mathrm{Sr}$ & 78 & 12 & 40 & 16 & 32 & 6 \\
\hline $\mathrm{Pb}$ & 26 & 5 & 19 & 7 & 23 & 6 \\
\hline $\mathrm{Ba}$ & 286 & 68 & 89 & 89 & 66 & 29 \\
\hline $\mathrm{Rb}$ & 291 & 29 & 356 & 55 & 500 & 47 \\
\hline Cs & 17 & 9 & 19 & 4 & 51 & 22 \\
\hline W & 6 & 1 & 9 & 5 & 9 & 2 \\
\hline $\mathrm{Ta}$ & * & & * & & 6 & 4 \\
\hline $\mathrm{U}$ & 8 & 3 & 11 & 6 & 13 & 5 \\
\hline Th & 12 & 6 & 10 & 7 & * & \\
\hline $\mathrm{Hf}$ & $*$ & & * & & * & \\
\hline $\mathbf{n}$ & 17 & & 5 & & 8 & \\
\hline $\mathrm{La}$ & 25.70 & 1.52 & 21.11 & & 10.97 & \\
\hline $\mathrm{Ce}$ & 55.02 & 3.25 & 44.60 & & 26.31 & \\
\hline $\mathrm{Nd}$ & 24.28 & 1.63 & 21.40 & & 15.90 & \\
\hline $\mathrm{Sm}$ & 5.53 & 0.59 & 4.47 & & 2.39 & \\
\hline $\mathrm{Eu}$ & 0.64 & 0.06 & 0.45 & & 0.23 & \\
\hline $\mathrm{Gd}$ & 6.36 & 1.13 & 5.10 & & 2.50 & \\
\hline $\mathrm{Tb}$ & 0.88 & 0.04 & 0.59 & & 0.30 & \\
\hline $\mathrm{Yb}$ & 0.71 & 0.08 & 0.37 & & 0.34 & \\
\hline $\mathrm{Lu}$ & 0.15 & 0.02 & 0.08 & & 0.06 & \\
\hline $\mathrm{n}$ & 5 & & 1 & & 2 & \\
\hline
\end{tabular}

Table headings as in Table 1. s.d. - standard deviation, ${ }^{*}$ - below the limit of sensitivity; $\mathrm{n}$ number of analysed samples. Analyst: M.E.P.Gomes. 

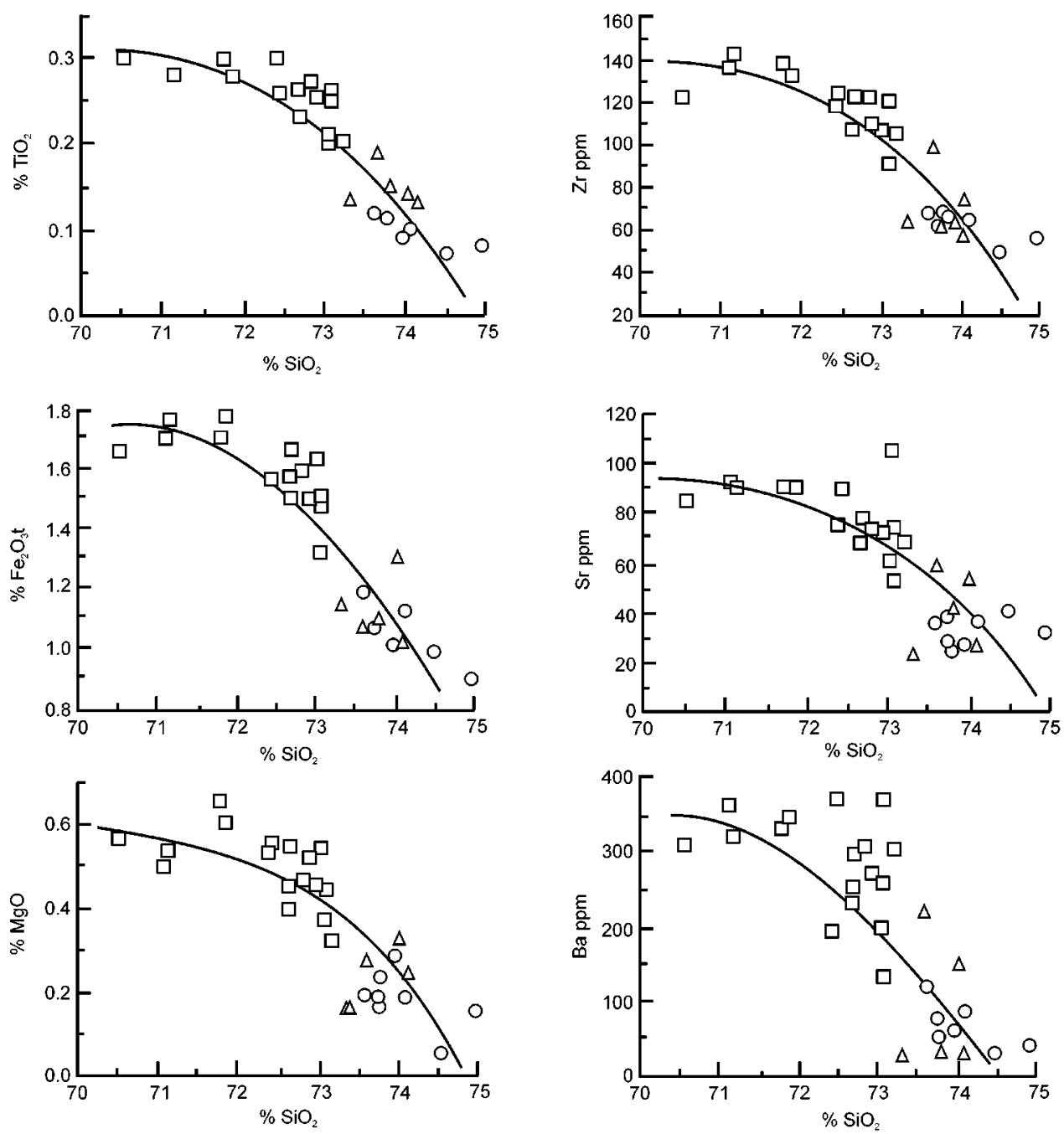

\section{Whole-rock geochemistry}

The average major element, trace element and rare earth contents of tin-bearing granites from Ervedosa are given in Table 2. They are peraluminous leucogranites with a molecular $\mathrm{A} /(\mathrm{CNK})$ ratio $\mathrm{Al}_{2} \mathrm{O}_{3} /\left(\mathrm{CaO}+\mathrm{Na}_{2} \mathrm{O}+\mathrm{K}_{2} \mathrm{O}\right)$ ranging from 1.1 to 1.4 and a normative corundum content of 1.7-4.8.

Selected elemental variation diagrams plotted against $\mathrm{SiO}_{2}$ show regular trends given by curves from the muscovite-biotite granite M1 to the muscovite granite M3 (Fig. 3), indicating fractional crystallization.

The chondrite-normalized REE patterns of the three granites are subparallel (Fig. 4). REE and the enrichment in light REE (LREE) with respect to heavy REE (HREE) decrease, while the negative Eu anomaly increases slightly from M1 to M3. The decrease 

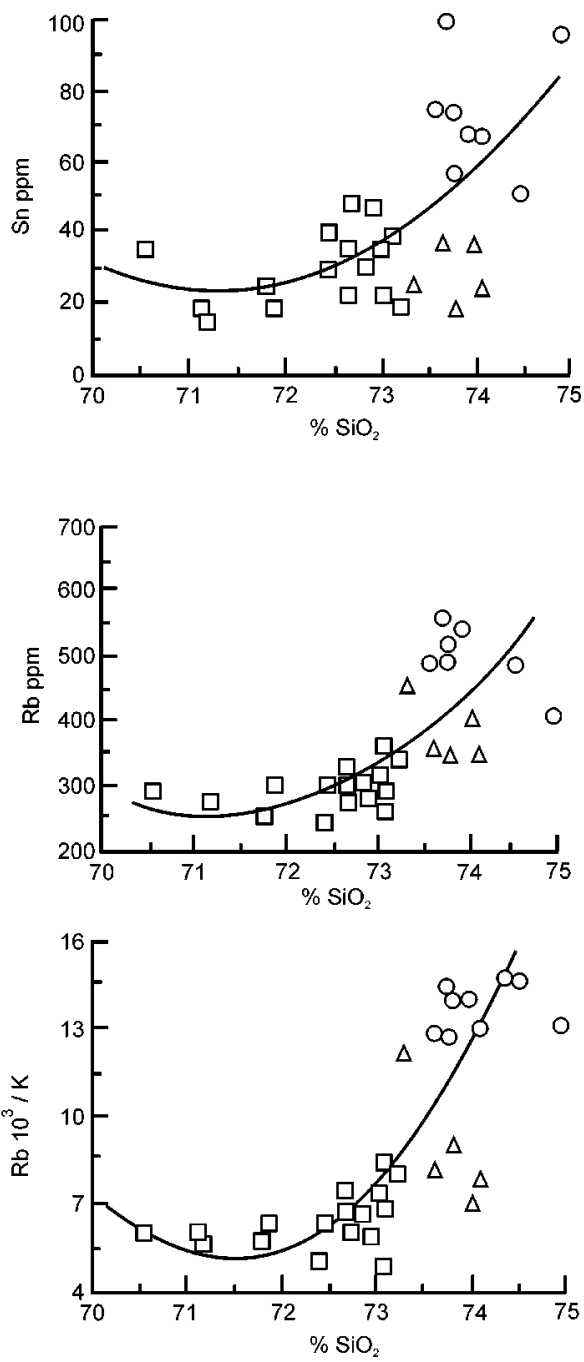

Fig. 3. Variation diagrams of major and trace elements of tin-bearing granites from Ervedosa. Symbols: $\square-$ medium-grained slightly porphyritic muscovite-biotite granite (M1), $\triangle$ medium- to fine-grained muscovite-biotite granite (M2), $\bigcirc$ - fine- to medium-grained muscovite granite (M3).

in LREE from M1 to M3 can be explained by fractionation of monazite (e.g., Bea 1996), while the decrease in medium REE (MREE) and HREE can be due to apatite fractionation and the decrease in HREE can also be attributed to zircon fractionation (e.g., Mittlefehldt and Miller 1983) because xenotime was not found.

\section{Isotopic data}

Isotopic $\mathrm{Rb}-\mathrm{Sr}$ analytical data are presented in Table 3 (Gomes 1996). The muscovitebiotite granite M1 is the oldest according to the field relationships and has a whole-rock $\mathrm{Rb}-\mathrm{Sr}$ isochron age of $328 \pm 9 \mathrm{Ma}$ (Fig. 5a). The three granites define a whole-rock $\mathrm{Rb}-\mathrm{Sr}$ isochron, which yields an age of $327 \pm 9$ Ma (Fig. 5b). Compared with that of granitic 


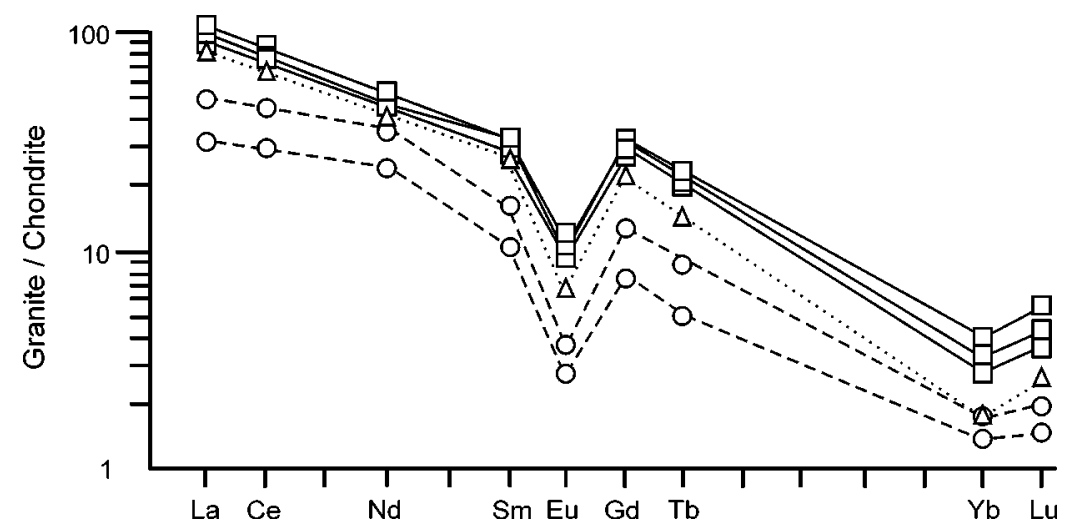

Fig. 4. Chondrite normalized REE abundances of tin-bearing granites from Ervedosa. Symbols as in Fig. 3. - M1, …… M2, ---- M3.
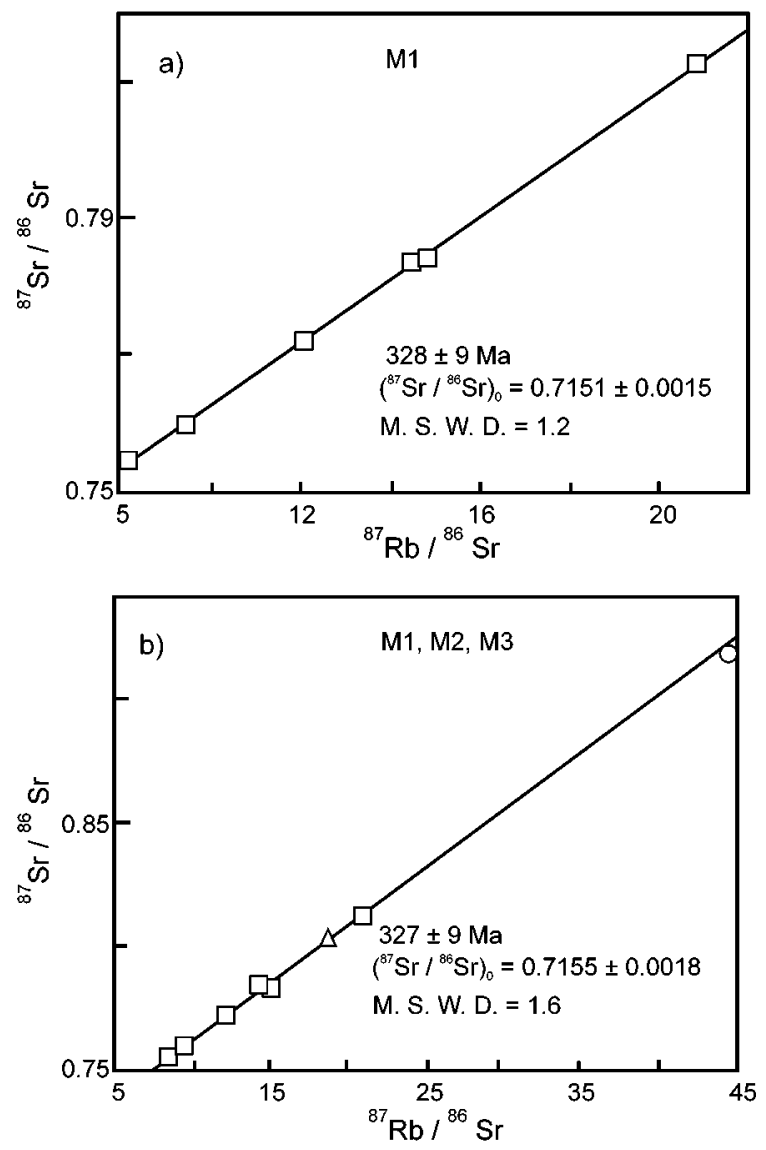

Fig. 5. Whole-rock Rb-Sr isochrons of a) muscovite-biotite granite $\mathrm{M} 1$ and $\mathrm{b}$ ) the three tin-bearing granites M1, M2 and M3 from Ervedosa. Symbols as in Fig. 3. 
Table 3. Rb-Sr analytical data for the tin-bearing granites from Ervedosa.

\begin{tabular}{|c|c|c|c|c|c|c|}
\hline Rock-type & $\mathrm{Rb}(\mathrm{ppm})$ & $\mathrm{Sr}(\mathrm{ppm})$ & ${ }^{87} \mathrm{Sr} /{ }^{86} \mathrm{Sr}$ & $\begin{array}{l}\% \text { error on } \\
{ }^{87} \mathrm{Sr} /{ }^{86} \mathrm{Sr}\end{array}$ & ${ }^{87} \mathrm{Rb} /{ }^{86} \mathrm{Sr}$ & $\left({ }^{87} \mathrm{Sr} /{ }^{86} \mathrm{Sr}\right)_{327 \mathrm{Ma}}$ \\
\hline \multicolumn{7}{|l|}{ Granite M1 } \\
\hline $\mathrm{a}$ & 236.5 & 74.7 & 0.75885 & 0.0064 & 9.5104 & 0.7146 \\
\hline $\mathrm{b}$ & 251.6 & 90.6 & 0.75410 & 0.0027 & 8.2516 & 0.7157 \\
\hline $\mathrm{c}$ & 321.9 & 67.5 & 0.78290 & 0.0026 & 14.4197 & 0.7158 \\
\hline d & 347.3 & 51.6 & 0.81251 & 0.0062 & 20.8081 & 0.7157 \\
\hline $\mathrm{e}$ & 336.0 & 68.2 & 0.78370 & 0.0026 & 14.8069 & 0.7148 \\
\hline $\mathrm{f}$ & 295.9 & 73.4 & 0.77155 & 0.0065 & 12.1147 & 0.7152 \\
\hline \multicolumn{7}{|l|}{ Granite M2 } \\
\hline$\underline{\mathrm{a}}$ & 351.10 & 57.7 & 0.80350 & 0.0037 & 18.6267 & 0.7168 \\
\hline \multicolumn{7}{|l|}{ Granite M3 } \\
\hline $\mathrm{a}$ & 483.45 & 35.1 & 0.92066 & 0.0043 & 44.7026 & 0.7126 \\
\hline
\end{tabular}

M1, M2 and M3 as in Table 1.

Table 4. Compositions of feldspars of tin-bearing granites from Ervedosa.

\begin{tabular}{lllll}
\hline & & M1 & M2 & M3 \\
\hline \multirow{2}{*}{ Or content of K-feldspar } & Phenocrysts & $\mathrm{Or}_{88}$ & $\mathrm{Or}_{90}$ & $\mathrm{Or}_{87}$ \\
& Matrix & $\mathrm{Or}_{89-95}$ & $\mathrm{Or}_{91-95}$ & $\mathrm{Or}_{94-98}$ \\
& Phenocrysts & $\mathrm{An}_{16}$ & - & - \\
An content of plagioclase & Matrix & $\mathrm{An}_{4-14}$ & $\mathrm{An}_{1-5}$ & $\mathrm{An}_{0-2}$ \\
\hline
\end{tabular}

Column headings as in Table 1.

rocks from the Iberian Massif (Pinto et al. 1987), this age corresponds to that of syntectonic granites. The medium- to coarse-grained porphyritic muscovite-biotite granite (319 $\pm 7 \mathrm{Ma}$; Gomes 1996) surrounds the oldest biotite-muscovite granite (357 $\pm 9 \mathrm{Ma}$; Gomes 1996) and the granites M1 and M2, with contacts that are sharp. The high initial ${ }^{87} \mathrm{Sr} /{ }^{86} \mathrm{Sr}$ ratio of $0.7151 \pm 0.0015$ (Fig. 5a) for granite $\mathrm{M} 1$ (Table 3) and its $\varepsilon \mathrm{Nd}_{\mathrm{T}}=-4.9$ and $\mathrm{T}_{\mathrm{DM}}=$ $1.41 \mathrm{Ga}$ (Gomes 1996) suggest that it is derived from partial melting of metasedimentary materials.

\section{Mineral Chemistry}

- Feldspars: Compositions of K-feldspar and plagioclase are given in Table 4. Matrix microcline has higher orthoclase content than that of the respective phenocryst microcline. There is decrease in anorthite content from phenocrysts to matrix plagioclases 
Table 5. Average chemical analyses in wt. $\%$ and trace elements in ppm of primary micas of tinbearing granites from Ervedosa.

\begin{tabular}{|c|c|c|c|c|c|c|c|c|c|}
\hline & \multicolumn{6}{|c|}{ Muscovite } & \multicolumn{3}{|c|}{ Biotite } \\
\hline & M1 & s.d. & M2 & s.d. & M3 & s.d. & M1 & s.d. & M2 \\
\hline $\mathrm{SiO}_{2}$ & 45.87 & 0.76 & 46.41 & 0.77 & 46.40 & 0.68 & 35.34 & 0.54 & 36.13 \\
\hline $\mathrm{TiO}_{2}$ & 0.63 & 0.19 & 0.68 & 0.41 & 0.34 & 0.16 & 2.69 & 0.45 & 2.18 \\
\hline $\mathrm{Al}_{2} \mathrm{O}_{3}$ & 35.32 & 0.98 & 34.82 & 0.89 & 33.77 & 1.34 & 19.05 & 0.57 & 20.48 \\
\hline $\mathrm{Fe}_{2} \mathrm{O}_{3}$ & 0.50 & 0.26 & 0.62 & 0.16 & 0.92 & 0.64 & 2.36 & 1.22 & 3.33 \\
\hline $\mathrm{FeO}$ & 0.84 & 0.23 & 1.22 & 0.54 & 2.58 & 0.55 & 21.09 & 1.16 & 20.22 \\
\hline $\mathrm{MnO}$ & 0.02 & 0.03 & 0.01 & 0.03 & 0.04 & 0.06 & 0.19 & 0.13 & 0.23 \\
\hline $\mathrm{MgO}$ & 0.71 & 0.18 & 0.74 & 0.16 & 0.62 & 0.32 & 6.38 & 0.91 & 4.44 \\
\hline $\mathrm{CaO}$ & 0.03 & 0.08 & 0.00 & & 0.00 & & 0.03 & 0.04 & 0.03 \\
\hline $\mathrm{Na}_{2} \mathrm{O}$ & 0.63 & 0.16 & 0.83 & 0.22 & 0.47 & 0.17 & 0.45 & 0.31 & 0.46 \\
\hline $\mathrm{K}_{2} \mathrm{O}$ & 10.34 & 0.44 & 10.20 & 0.37 & 10.35 & 0.56 & 9.32 & 0.24 & 9.11 \\
\hline $\mathrm{F}$ & 0.14 & 0.03 & 0.29 & 0.10 & 0.45 & 0.01 & 0.33 & 0.05 & 0.45 \\
\hline \multirow[t]{2}{*}{$\mathrm{Cl}$} & 0.03 & 0.01 & 0.03 & 0.01 & 0.03 & 0.01 & 0.05 & 0.01 & 0.04 \\
\hline & 95.06 & & 95.85 & & 95.97 & & 97.28 & & 97.10 \\
\hline $\mathrm{O} \equiv \mathrm{F}$ & 0.06 & & 0.12 & & 0.19 & & 0.14 & & 0.19 \\
\hline $\mathrm{O} \equiv \mathrm{Cl}$ & 0.01 & & 0.01 & & 0.01 & & 0.01 & & 0.01 \\
\hline $\begin{array}{l}---- \\
\text { Total }\end{array}$ & 94.99 & & 95.72 & . & 95.77 & 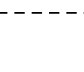 & 97.13 & 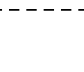 & 96.90 \\
\hline $\mathrm{Cr}$ & 31 & 9 & 15 & 3 & 9 & 3 & 101 & 24 & 59 \\
\hline $\mathrm{V}$ & 67 & 11 & 41 & 15 & 20 & 9 & 175 & 30 & 104 \\
\hline $\mathrm{Nb}$ & 76 & 13 & 111 & 19 & 176 & 53 & 207 & 30 & 311 \\
\hline $\mathrm{Zn}$ & 73 & 18 & 144 & 63 & 215 & 66 & 851 & 290 & 1170 \\
\hline Sn & 113 & 31 & 152 & 59 & 423 & 77 & 137 & 22 & 258 \\
\hline $\mathrm{Li}$ & 266 & 160 & 557 & 329 & 857 & 293 & 1378 & 494 & 2313 \\
\hline $\mathrm{Ni}$ & 11 & 4 & 20 & 9 & 55 & 17 & 67 & 8 & 76 \\
\hline $\mathrm{Zr}$ & 35 & 10 & 21 & 6 & 23 & 8 & 89 & 37 & 93 \\
\hline $\mathrm{Sc}$ & 17 & 10 & 13 & 6 & 8 & 1 & 10 & 7 & 3 \\
\hline $\mathrm{Y}$ & 48 & 3 & 56 & 7 & 111 & 62 & 85 & 54 & 90 \\
\hline $\mathrm{Sr}$ & 24 & 2 & 19 & 2 & 20 & 4 & 20 & 3 & 21 \\
\hline $\mathrm{Ba}$ & 181 & 43 & 80 & 51 & 66 & 22 & $*$ & & $*$ \\
\hline $\mathrm{Rb}$ & 799 & 115 & 1243 & 279 & 2269 & 409 & 1379 & 432 & 2296 \\
\hline $\mathrm{Cs}$ & 16 & 7 & 31 & 20 & 85 & 26 & 127 & 44 & 393 \\
\hline $\mathrm{Ta}$ & 35 & 66 & 18 & 9 & 34 & 15 & 24 & 13 & 107 \\
\hline $\mathrm{Ce}$ & 26 & 10 & 15 & 8 & 29 & 15 & 59 & 22 & 62 \\
\hline $\mathrm{Nd}$ & 7 & 2 & 8 & 7 & 9 & 3 & 12 & 8 & 11 \\
\hline $\mathrm{La}$ & 22 & 5 & 24 & 3 & 30 & 5 & 31 & 10 & 61 \\
\hline $\mathrm{n}$ & 15 & & 5 & & 12 & & 14 & & 2 \\
\hline
\end{tabular}

Column headings as in Table 1. s.d. - standard deviation; * - below the limit of detection; $\mathrm{n}-$ number of samples with analysed micas. Analyst: M.E.P.Gomes. 

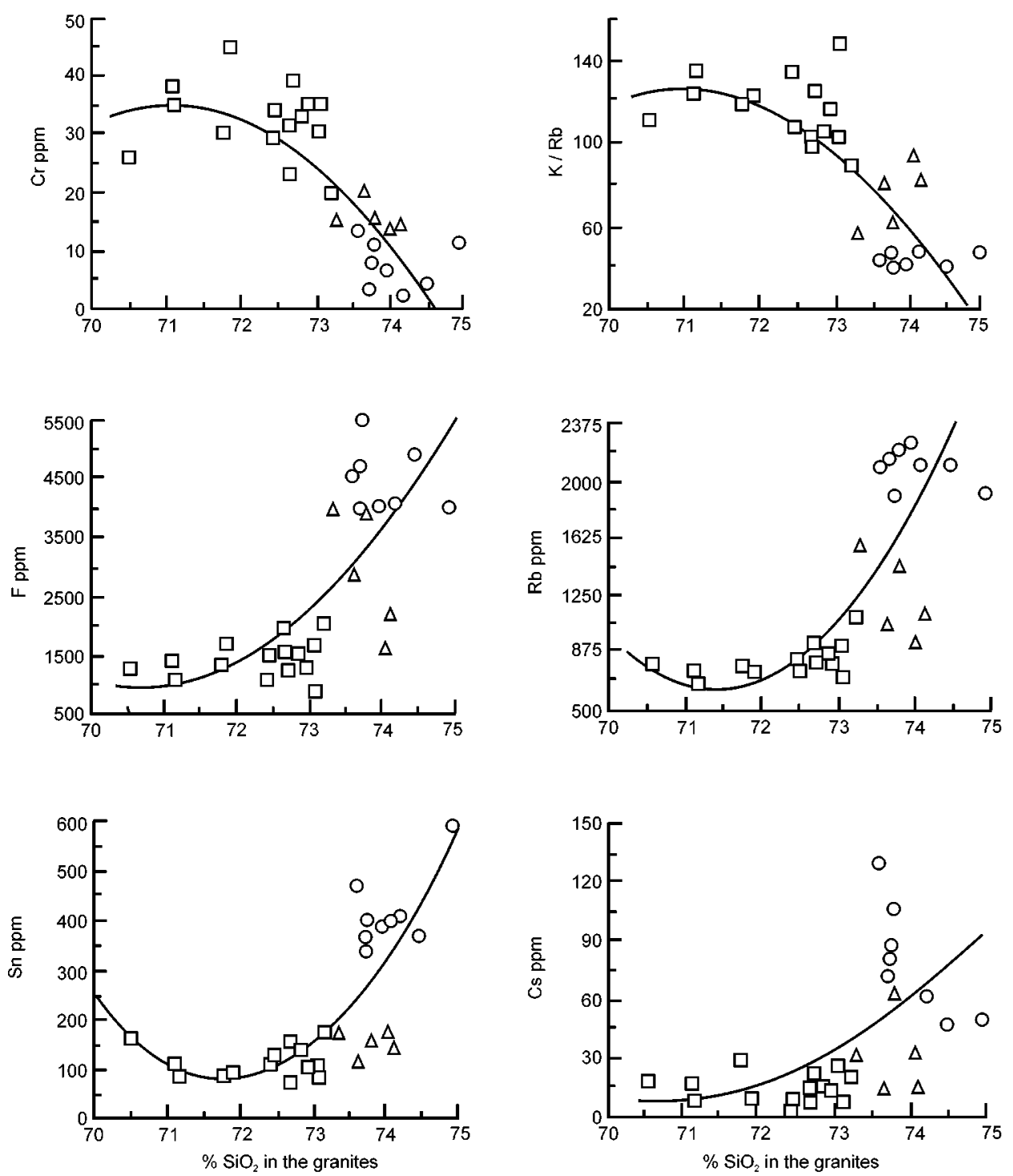

Fig. 6. Variation diagrams of trace elements of primary muscovites of tin-bearing granites from Ervedosa. Symbols as in Fig. 3.

of M1. There is a tendency for a slight increase in orthoclase content of matrix microcline, while there is decrease in anorthite content of matrix plagioclase from the muscovite-biotite granite M1 to the muscovite granite M3.

- Micas: The average major and trace elements concentrations of the analyzed primary muscovite and biotite of each granite type are given in Table 5. A trend was found from primary muscovite of granite M1 to that of granite M3 (Fig. 6). 

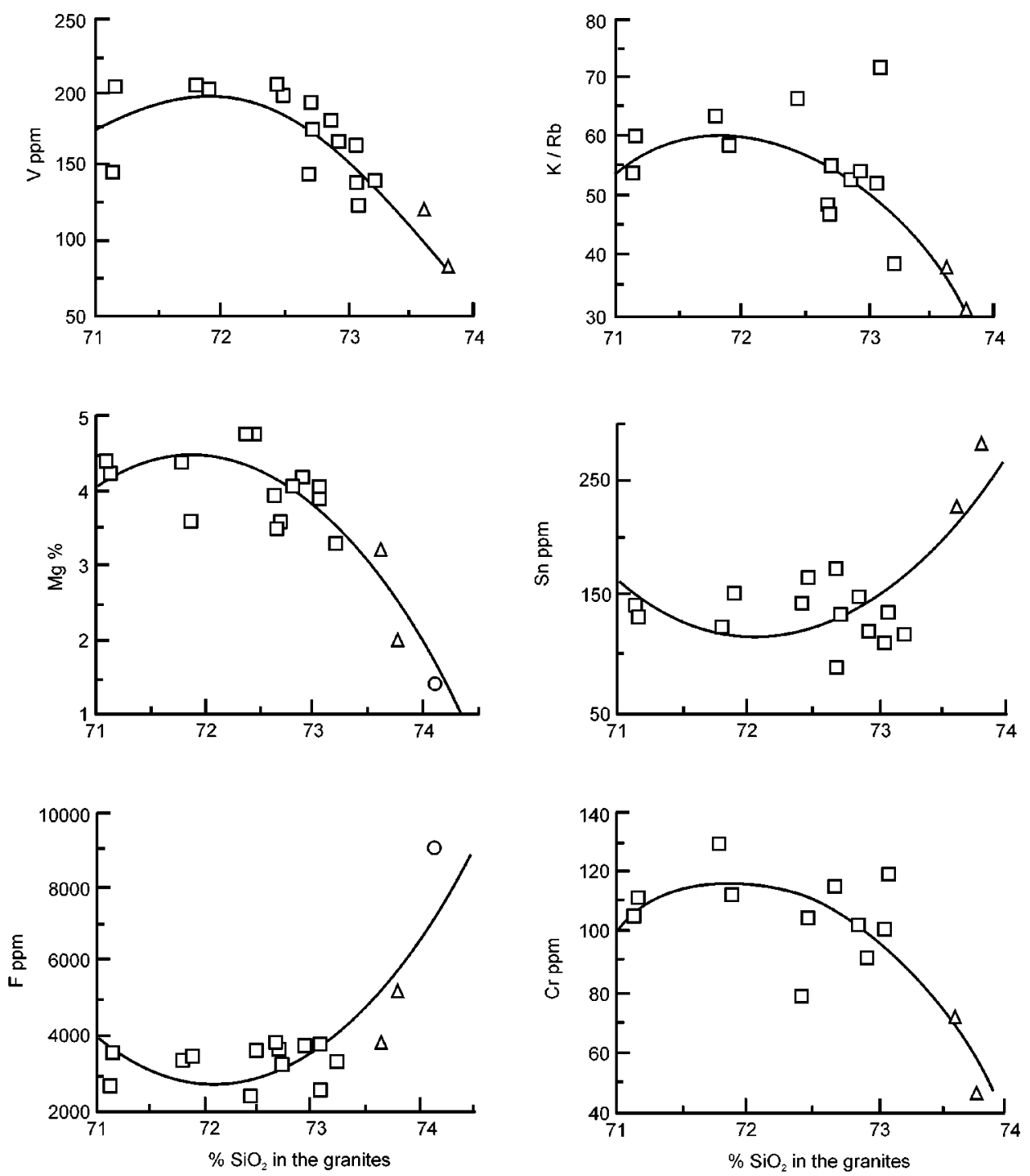

Fig. 7. Variation diagrams of major and trace elements of biotites of tin-bearing granites from Ervedosa. Symbols as in Fig. 3.

All biotites are $\mathrm{Fe}^{2+}$-biotite (Foster 1960) and Al-K biotite (Nachit et al. 1985), corresponding to plutonic biotites of igneous origin (Gokhale 1968) and of peraluminous S-type suites (Abdel-Rahman 1994). Plotted in the $\mathrm{Al}_{2} \mathrm{O}_{3}$-total $\mathrm{FeO}-\mathrm{MgO}$ triangle they fall in the field of coexistence with muscovite (Nockolds 1947); this agrees with the petrographic observations. A trend is defined from biotite of granite M1 to that of biotite of granite M3 (Fig. 7). Due to the low amount of biotite in granite M3, the contents of trace elements of this mica could not be determined. 
- Partition of elements between coexisting micas: Partition ratios were calculated by dividing the concentration of any element in biotite by its content in the coexisting primary muscovite. The concentrations of trace elements in biotite are generally higher than in coexisting muscovite (Table 6), but Sr does not show any preference, while Sc partitions preferentially into muscovite. The partition ratios calculated for $\mathrm{Ti}, \mathrm{Mg}, \mathrm{F}$ and $\mathrm{Rb}$ between coexisting biotite and muscovite are similar to those of Icenhower and London (1995).

The partition ratio for $\mathrm{Ti}(3.4-5.2)$ between coexisting biotite and muscovite of granites from Ervedosa are close to those of equilibrium 3.3-4.5 for Ti of coexisting micas from pelitic schists (Guidotti et al. 1977).

The distribution coefficient $\mathrm{K}_{\mathrm{D}}$ for $\mathrm{Fe}$ and $\mathrm{Mg}$ between coexisting micas from Ervedosa was calculated by the equation $K_{D}=\left[X_{M g}^{M}\left(1-X_{M g}^{B}\right)\right] /\left[X_{M g}^{B}\left(1-X_{M g}^{M}\right)\right]$, where $\mathrm{X}_{\mathrm{Mg}}^{\mathrm{M}}=\mathrm{Mg} /\left(\mathrm{Mg}+\mathrm{Fe}^{2+}\right)$ in muscovite and $\mathrm{X}_{\mathrm{Mg}}^{\mathrm{B}}=\mathrm{Mg} /\left(\mathrm{Mg}+\mathrm{Fe}^{2+}\right)$ in biotite, with the concentrations expressed as cationic proportions. $K_{D}$ ranges between 2.9 and 3.3 , showing departure from equilibrium where $K_{D}$ is $1-1.5$ (Butler 1967).

The best correlations found between coexisting biotite and muscovite contents from Ervedosa are for $\mathrm{K} / \mathrm{Rb}, \mathrm{Nb}, \mathrm{Li}, \mathrm{Li} / \mathrm{Mg}, \mathrm{Sn}, \mathrm{Rb}$ (Fig. 8) suggesting that equilibrium was attained for these elements, which agrees with findings of others authors, namely for $\mathrm{Li}$ (Godinho and Silva 1974), Li/Mg (Neiva 1977), Nb (Neves 1997) and K/Rb (Albuquerque 1975).

- Accessory minerals: Accessory minerals are common in granites. Chemical analyses of zircon, monazite and apatite are given in Table 7. In general, zircon from the muscovite granite $\mathrm{M} 3$ is richer in $\mathrm{Fe}+\mathrm{Th}+\mathrm{Hf}+\mathrm{U}$ and poorer in $\mathrm{Zr}+\mathrm{Si}$ than zircon of muscovite-biotite granite M1 (Fig. 9a). In more differentiated rocks, zircon displays complimentary increases in $\mathrm{Hf}$ and $\mathrm{Y}$ and higher $\mathrm{U}$ and Th concentration (Wark and Miller 1993).

The monazite, from the Ervedosa granites, plots between the brabantite and xenotime components; it defines a trend close and parallel to the brabantite substitution (Figs. 9b, c). The predominance of brabantite substitution is characteristic of highly differentiated granites (Föster 1998). The monazite from the muscovite granite M3 is the poorest in LREE and the richest in $\mathrm{Th}+\mathrm{U}$ (Table 7).

Table 6. Average partitioning (D) of elements between coexisting biotite and muscovite of tinbearing granites from Ervedosa.

\begin{tabular}{lccccccccccc}
\hline & $\mathrm{Ti}$ & $\mathrm{Mg}$ & $\mathrm{Fe}$ & $\mathrm{Cl}$ & $\mathrm{F}$ & $\mathrm{Cr}$ & $\mathrm{V}$ & $\mathrm{Nb}$ & $\mathrm{Zn}$ & $\mathrm{Sn}$ & $\mathrm{Li}$ \\
\hline $\mathrm{D}$ & 4.3 & 9.0 & 24.9 & 1.8 & 2.3 & 3.2 & 2.6 & 2.8 & 10.7 & 1.4 & 5.2 \\
s.d. & 1.8 & 3.0 & 6.6 & 0.5 & 0.6 & 0.9 & 0.5 & 0.6 & 3.2 & 0.3 & 1.8 \\
& $\mathrm{Ni}$ & $\mathrm{Zr}$ & $\mathrm{Sc}$ & $\mathrm{Y}$ & $\mathrm{Sr}$ & $\mathrm{Rb}$ & $\mathrm{Cs}$ & $\mathrm{Ta}$ & $\mathrm{La}$ & $\mathrm{Ce}$ & $\mathrm{Nd}$ \\
\hline $\mathrm{D}$ & 5.8 & 2.9 & 0.7 & 1.8 & 0.9 & 1.8 & 10.8 & 3.0 & 21.5 & 2.6 & 0.9 \\
s.d. & 2.9 & 1.7 & 0.3 & 1.2 & 0.2 & 0.5 & 8.4 & 2.3 & 0.8 & 2.6 & 0.8 \\
\hline
\end{tabular}

D - concentration of element in biotite/concentration of element in muscovite; s.d. - standard deviation calculated for 16 pairs. 

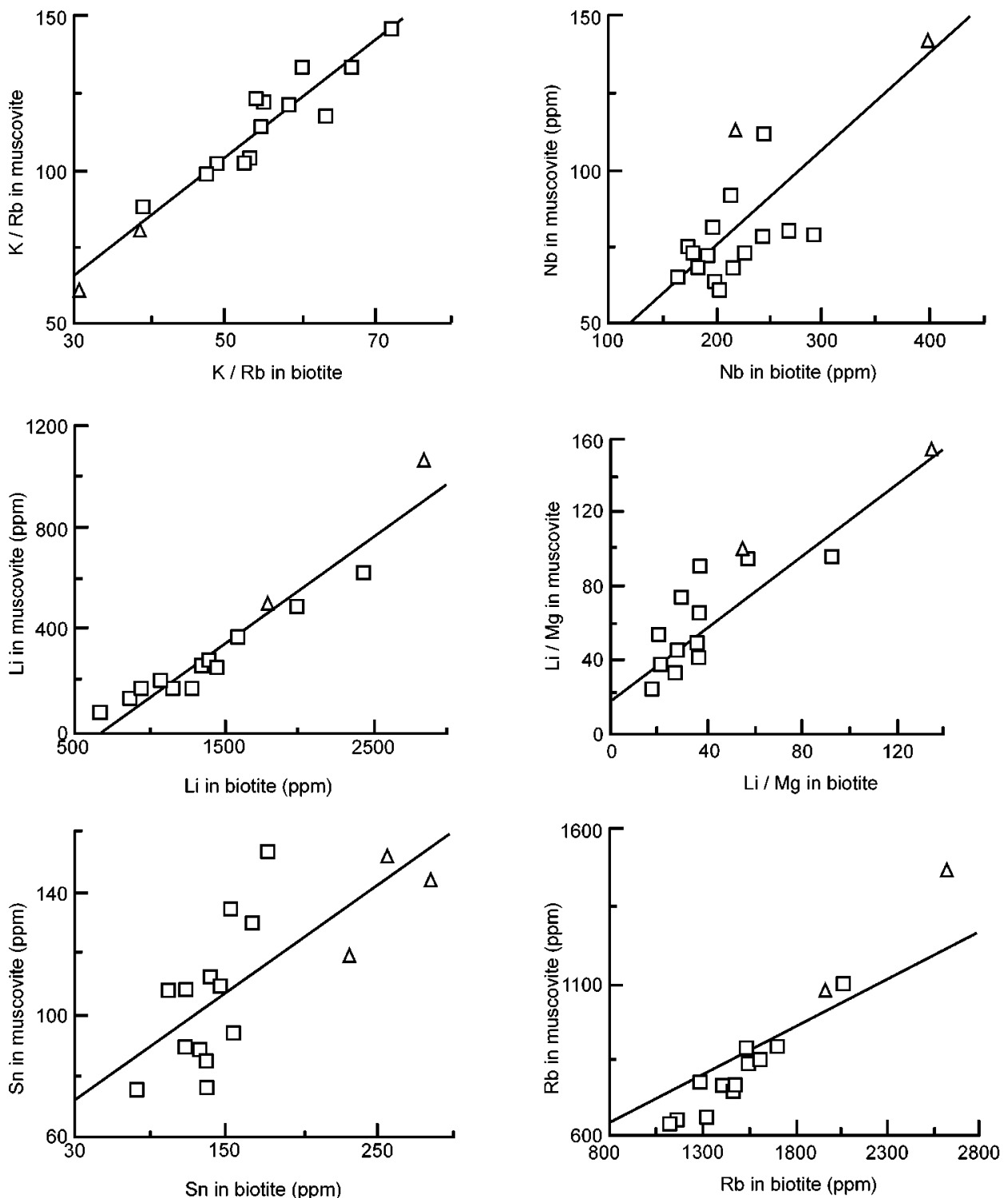

Fig. 8. Correlations for $\mathrm{Li}, \mathrm{Li} / \mathrm{Mg}, \mathrm{Nb}, \mathrm{Sn}, \mathrm{Rb}$ and $\mathrm{K} / \mathrm{Rb}$ between coexisting biotite and muscovite of granites from Ervedosa. Symbols as in Fig. 3.

The apatite from muscovite granite $\mathrm{M} 3$ tends to be the richest in $\mathrm{REE}+\mathrm{Si}$ and the poorest in $\mathrm{Ca}+\mathrm{P}$ (Table 7, Fig. 9d). $\mathrm{Cl}$ and $\mathrm{F}$ have been determined on apatite, but the values are below the limit of detection.

Ilmenite occurs in all granites and its Mn content ranges between 0.122 and $0.596 \mathrm{pfu}$, increasing progressively from the ilmenite of the muscovite-biotite granite M1 to that of the muscovite granite M3. A negative correlation was found between $\mathrm{Ti}_{\text {and }} \mathrm{Fe}^{2+}+\mathrm{Mn}$ of ilmenite. 
Table 7. Average chemical analyses in wt. \% of accessory minerals of tin-bearing granites from Ervedosa.

\begin{tabular}{|c|c|c|c|c|c|c|c|c|}
\hline & \multicolumn{2}{|c|}{ Zircon } & \multicolumn{3}{|c|}{ Monazite } & \multicolumn{3}{|c|}{ Apatite } \\
\hline & M1 & M3 & M1 & M2 & M3 & M1 & M2 & M3 \\
\hline $\mathrm{SiO}_{2}$ & 30.41 & 24.45 & $*$ & $*$ & $*$ & 0.21 & 0.12 & 0.23 \\
\hline $\mathrm{ZrO}_{2}$ & 61.68 & 53.61 & - & - & - & - & - & - \\
\hline $\mathrm{HfO}_{2}$ & 1.26 & 1.56 & - & - & - & - & - & - \\
\hline $\mathrm{TiO}_{2}$ & 0.11 & 0.12 & 1.14 & 1.01 & 1.16 & - & - & - \\
\hline $\mathrm{Al}_{2} \mathrm{O}_{3}$ & 0.06 & 1.26 & 0.51 & 0.54 & 0.40 & 0.42 & 1.16 & 1.85 \\
\hline $\mathrm{FeO}$ & 0.31 & 1.68 & 1.95 & 1.24 & 1.68 & 3.38 & 4.25 & 4.19 \\
\hline $\mathrm{MnO}$ & 0.01 & 0.11 & $*$ & $*$ & 0.01 & 0.01 & 0.03 & 0.04 \\
\hline $\mathrm{La}_{2} \mathrm{O}_{3}$ & - & - & 11.71 & 11.62 & 10.94 & 0.07 & 0.06 & 0.06 \\
\hline $\mathrm{Ce}_{2} \mathrm{O}_{3}$ & 0.04 & 0.13 & 28.04 & 26.71 & 26.18 & 0.10 & $*$ & 0.03 \\
\hline $\mathrm{Nd}_{2} \mathrm{O}_{3}$ & 0.03 & 0.08 & 10.90 & 10.51 & 10.36 & - & - & - \\
\hline $\mathrm{Sm}_{2} \mathrm{O}_{3}$ & 0.05 & 0.02 & 1.67 & 1.55 & 1.60 & - & - & - \\
\hline $\mathrm{Gd}_{2} \mathrm{O}_{3}$ & 0.11 & 0.16 & - & - & - & - & - & - \\
\hline $\mathrm{Dy}_{2} \mathrm{O}_{3}$ & 0.09 & 0.13 & - & - & - & - & - & - \\
\hline $\mathrm{MgO}$ & 0.01 & 0.21 & 0.01 & $*$ & $*$ & 0.02 & 0.03 & 0.02 \\
\hline $\mathrm{CaO}$ & - & - & 1.34 & 1.65 & 1.88 & 54.37 & 53.20 & 52.56 \\
\hline $\mathrm{Na}_{2} \mathrm{O}$ & 0.01 & 0.04 & 0.09 & 0.09 & 0.07 & 0.31 & 0.13 & 0.14 \\
\hline $\mathrm{K}_{2} \mathrm{O}$ & - & - & - & - & - & 0.10 & 0.15 & 0.10 \\
\hline $\mathrm{P}_{2} \mathrm{O}_{5}$ & - & - & 28.95 & 29.77 & 29.24 & 40.81 & 40.72 & 40.87 \\
\hline $\mathrm{ThO}_{2}$ & 0.11 & 0.69 & 5.97 & 7.70 & 8.78 & 0.01 & 0.01 & 0.01 \\
\hline $\mathrm{UO}_{2}$ & 0.78 & 1.28 & 0.58 & 0.73 & 0.88 & - & - & - \\
\hline $\mathrm{Y}_{2} \mathrm{O}_{3}$ & 0.70 & 1.12 & 0.69 & 0.95 & 0.90 & 0.01 & - & 0.01 \\
\hline Total $^{\mathrm{a}}$ & 95.77 & 86.65 & 93.55 & 94.07 & 94.08 & 99.82 & 99.86 & 100.11 \\
\hline
\end{tabular}

- not analyzed; $*$ - below the limit of detection; ${ }^{\text {a }}$ - low totals reflect presence of elements not analysed.

Cassiterite crystals are very rare, only found in granite M3 and of very small sizes. Therefore, it was impossible to analyze them. The cassiterite is interpreted as magmatic and derived from magmatic aqueous fluids with low salinities (Schwartz et al. 1995; Linnen 1998).

\section{Conditions of crystallization}

Melt temperatures were calculated by two different methods: a) the Zr content and the solubility model of Watson and Harrison (1983); b) REE and the solubility of monazite (Montel 1993). Temperatures range from 770 to $730{ }^{\circ} \mathrm{C}$ by the first method and from 836 to $744{ }^{\circ} \mathrm{C}$ by the second method, always showing a progressive decrease from M1 to M3 (Fig. 10). The two thermometers give similar results with a difference ranging between 14 and $66^{\circ} \mathrm{C}$, which may be attributed to analytical and experimental errors.

Based on the estimated temperatures for the melts by the $\mathrm{Zr}$ thermometer, biotite compositions and the work of Burkhard (1991), estimated $\mathrm{f}_{\mathrm{O}_{2}}$ is of $10^{-16}$ bars and $\mathrm{P}_{\mathrm{H}_{2} \mathrm{O}}$ of 3-4 kb. 

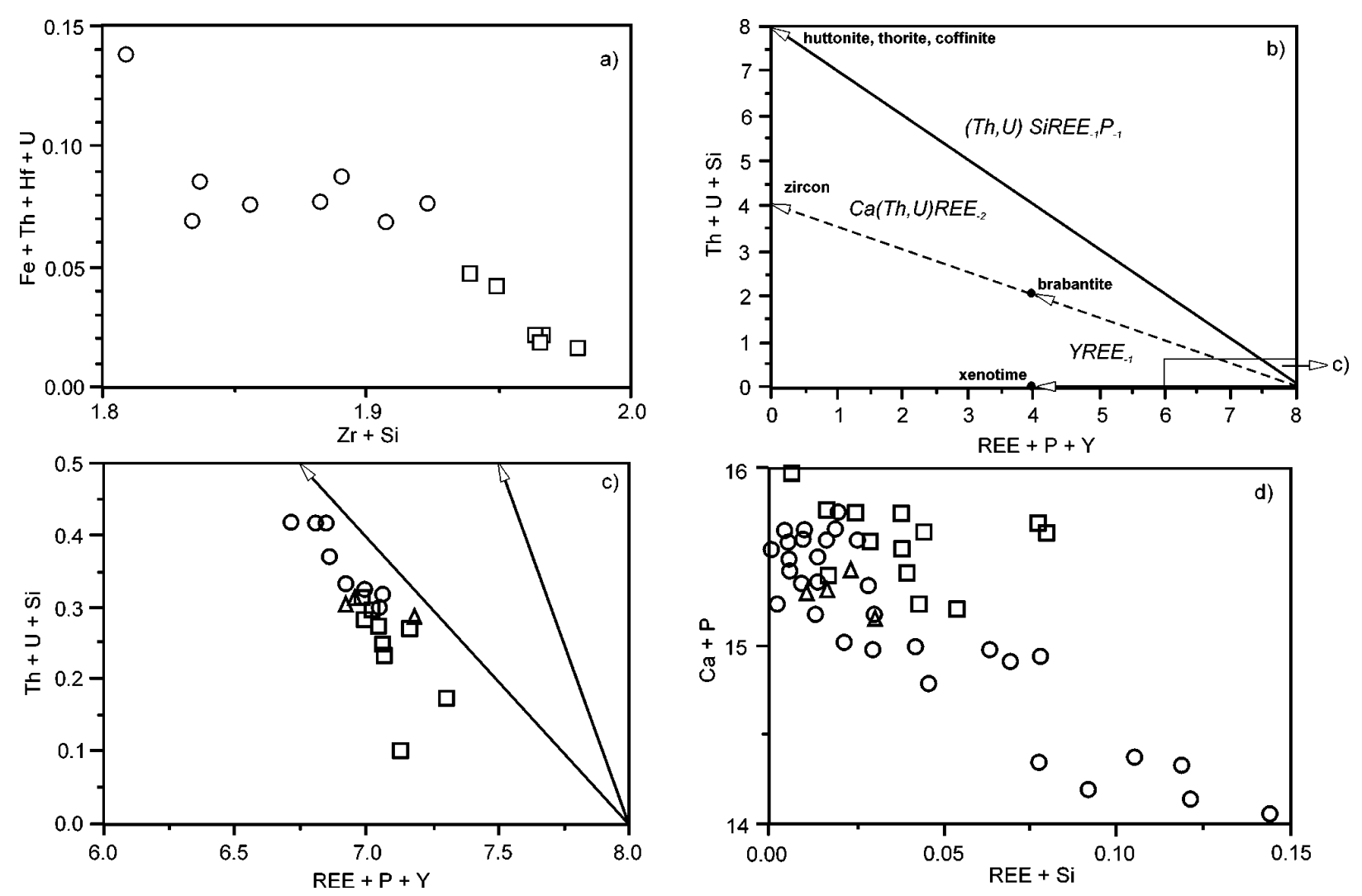

Fig. 9. Plots of accessory minerals from Ervedosa tin-bearing granites: a) Plot of atomic contents ( $\mathrm{Fe}+\mathrm{Th}+\mathrm{Hf}+\mathrm{U})$ versus $(\mathrm{Zr}+\mathrm{Si})$ of zircon; b) Plot of atomic contents $(\mathrm{Th}+\mathrm{U}+\mathrm{Si})$ versus $(\mathrm{REE}+\mathrm{P}+\mathrm{Y})$ of monazite, calculated on the basis of $16 \mathrm{O}$ atoms. The solid arrow represents the huttonite substitution and the dashed arrow the brabantitic substitution. In the lower corner, the area of Fig. 9c; c) Plot of monazite analyses.; d) Plot of atomic contents (Ca+P) versus (REE+Si) of apatite. Symbols as in Fig. 3. 
During the differentiation of muscovite-biotite granite magma M1, there was a progressive increase in wt. $\% \mathrm{~F}$ in melt $(0.15$ for $\mathrm{M} 1,0.39$ for $\mathrm{M} 2$ and 0.88 for $\mathrm{M} 3)$, which were calculated using the data on biotite (Table 5) and the experimental results of Icenhower and London (1997).

Temperatures estimated from the two-feldspar geothermometer of Elkins and Grove (1990) for the respective pressure range between 567 and $329^{\circ} \mathrm{C}$, which correspond to reequilibrium of feldspars under the subsolidus conditions.

\section{Petrogenesis}

The variation diagrams of tin-bearing granites (Fig. 3), muscovite (Fig. 6) and biotite (Fig. 7), the decrease in Ca of plagioclase (Table 4) and the increase in Th and U contents of zircon and monazite from the muscovite-biotite granite M1 to the muscovite granite M3 (Table 7 and Fig. 9) and the subparallel REE patterns of granites (Fig. 4) suggest a crystal fractionation model.

Major elements were used to test fractional crystallization (Table 8). The average composition of the five samples with the lowest $\mathrm{SiO}_{2}$ contents of granite $\mathrm{M} 1$ was selected as the parent magma. The most silicic samples (five of M1 and four of each granite type M2 and M3 that did not show any metasomatic effects) were taken as the residual liquids. Compositions of pure anorthite, albite and quartz were used, as well as compositions determined by electron microprobe of K-feldspar, micas and ilmenite. The sum of the squares of the residuals ( $\mathrm{R}^{2}$ ) was always 0.31 . The anorthite content of plagioclase of the cumulate was always similar to that of the highest anorthite content of plagioclase of the granite M1.

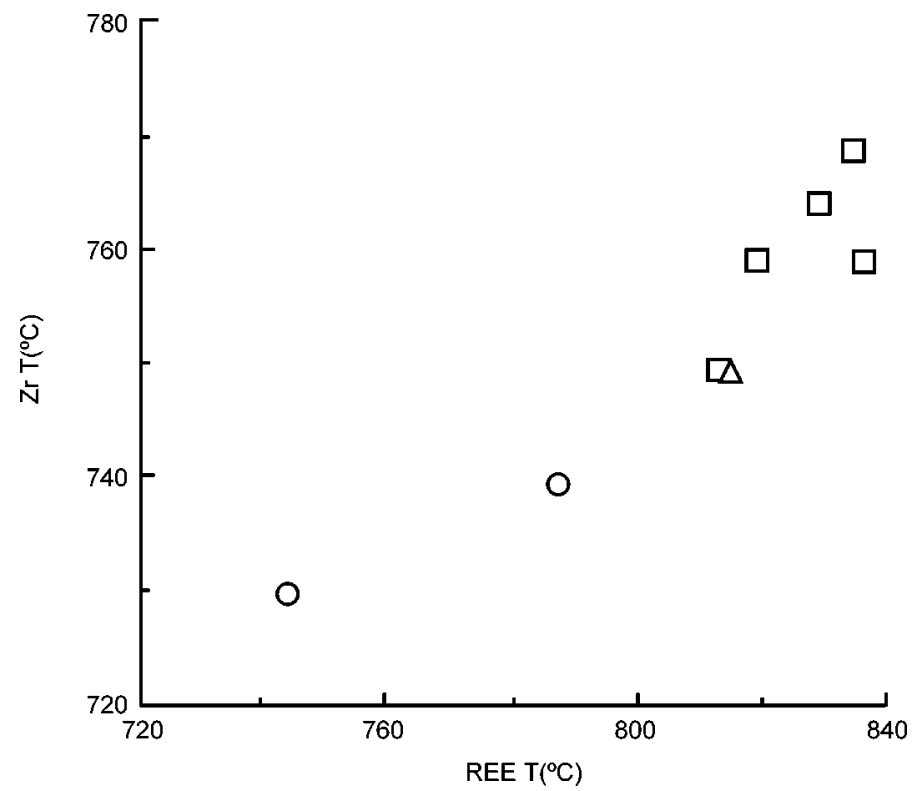

Fig. 10. Comparison between the temperature obtained by $\mathrm{Zr}$ thermometry (Watson \& Harrison 1983) and REE thermometry (Montel 1993). Symbols as in Fig. 3. 
The percentage of plagioclase and biotite decrease in cumulate versus the decrease in weight fraction of melt remaining during fractional crystallization (Table 8 and Figs. $11 \mathrm{a}, \mathrm{b}$ ).

The trace elements $\mathrm{Sr}, \mathrm{Ba}$ and $\mathrm{Rb}$ were modelled using the equation $\mathrm{C}_{\mathrm{L}}=\mathrm{C}_{0} \mathrm{~F}^{\mathrm{D}-1}$ for perfect fractional crystallization (Rayleigh fractionation) and the equation $\mathrm{C}_{\mathrm{L}}=$ $\mathrm{C}_{0} /\left(\mathrm{D}+\mathrm{F}(1-\mathrm{X})\right.$ for equilibrium crystallization. $\mathrm{C}_{\mathrm{L}}$ is the concentration of the element in the melt; $\mathrm{C}_{0}$ is the concentration of the element in the system; $\mathrm{F}$ is the fractionation of melt in the system; $\mathrm{D}=\mathrm{KiXi}$ is the bulk distribution coefficient of the element $\mathrm{i}$. The modal

Table 8. Results of fractional crystallization model of tin-bearing granites from Ervedosa.

\begin{tabular}{|c|c|c|c|c|}
\hline \multirow{2}{*}{\multicolumn{2}{|c|}{$\begin{array}{l}\text { Determined parent } \\
\text { magma (M1) }\end{array}$}} & \multicolumn{3}{|c|}{ Calculated composition of parent magma for } \\
\hline & & \multirow{2}{*}{$\begin{array}{l}\text { M1 (most silicic) } \\
72.3\end{array}$} & \multirow{2}{*}{ M2 } & \multirow{2}{*}{$\frac{\text { M3 }}{72.2}$} \\
\hline $\mathrm{SiO}_{2}$ & 72.2 & & & \\
\hline $\mathrm{TiO}_{2}$ & 0.3 & 0.2 & 0.2 & 0.3 \\
\hline $\mathrm{Al}_{2} \mathrm{O}_{3}$ & 15.4 & 15.4 & 15.5 & 15.5 \\
\hline $\mathrm{Fe}_{2} \mathrm{O}_{3} \mathrm{t}$ & 1.7 & 1.9 & 1.7 & 1.7 \\
\hline $\mathrm{MgO}$ & 0.6 & 0.6 & 0.6 & 0.4 \\
\hline $\mathrm{CaO}$ & 0.7 & 0.7 & 0.6 & 0.8 \\
\hline $\mathrm{Na}_{2} \mathrm{O}$ & 3.4 & 3.2 & 3.3 & 3.4 \\
\hline $\mathrm{K}_{2} \mathrm{O}$ & 5.7 & 5.3 & 5.6 & 5.7 \\
\hline $\mathrm{F}$ & & $0.937 \pm 0.022$ & $0.866 \pm 0.023$ & $0.628 \pm 0.242$ \\
\hline$\Sigma \mathrm{R}^{2}$ & & 0.19 & 0.07 & 0.07 \\
\hline
\end{tabular}

M1, M2 and M3 as in Table 1. F = Weight fraction of melt remaining during fractional crystallization;

$\Sigma \mathrm{R}^{2}=$ Sum of the squares of the residuals.

\section{Modal composition of cumulate}

\begin{tabular}{llll}
\hline Quartz & - & - & $21.7 \pm 13.0$ \\
K-feldspar & - & $48.1 \pm 11.3$ & $49.3 \pm 10.8$ \\
Plagioclase & $61.9 \pm 49.2$ & $27.8 \pm 16.4$ & $15.3 \pm 18.1$ \\
Biotite & $38.1 \pm 11.1$ & $21.8 \pm 6.0$ & $13.7 \pm 2.0$ \\
Ilmenite & - & $2.3 \pm 2.2$ & - \\
\hline
\end{tabular}

Compositions of residual melts

\begin{tabular}{|c|c|c|c|c|c|c|c|}
\hline & \multirow{2}{*}{$\begin{array}{l}\text { M1 (least } \\
\text { silicic } \\
\text { samples) } \\
\text { Deter- } \\
\text { mined }\end{array}$} & \multicolumn{2}{|c|}{ M1 (most silicic) } & \multicolumn{2}{|l|}{ M2 } & \multicolumn{2}{|l|}{ M3 } \\
\hline & & Calculated & $\begin{array}{l}\text { Deter- } \\
\text { mined }\end{array}$ & Calculated & $\begin{array}{l}\text { Deter- } \\
\text { mined }\end{array}$ & Calculated & $\begin{array}{l}\text { Deter- } \\
\text { mined }\end{array}$ \\
\hline Sr ppm & 90 & 60 & 70 & 41 & 45 & 25 & 26 \\
\hline $\mathrm{Rb}$ ppm & 279 & 282 & 309 & 282 & 358 & 307 & 490 \\
\hline Ba ppm & 336 & 250 & 252 & 120 & 105 & 60 & 18 \\
\hline
\end{tabular}


composition of cumulate and weight fraction of melt remaining $(\mathrm{F})$ during fractional crystallization were used; these were based on calculations involving major elements. The contents of $\mathrm{Sr}, \mathrm{Ba}$ and $\mathrm{Rb}$ in the average of the five least silicic samples of M1 were used. The distribution coefficients (K) used are given in Table 9. The results based on the equilibrium crystallization equation are closer to the analytical data than those based on the Rayleigh fractionation. $\mathrm{Rb}$ increases and $\mathrm{Sr}$ and $\mathrm{Ba}$ decrease, versus decrease in weight fraction of melt remaining during fractional crystallization (Table 8 and Figs. 11c, d). Particularly for $\mathrm{Sr}$ and $\mathrm{Ba}$, the calculated data is close to the analytical data (Figs. 11e, f).

The granites M1, M2 and M3 are syntectonic and deformed. The samples selected of the three granites to get isotopic $\mathrm{Rb}-\mathrm{Sr}$ data were the least deformed. The $\mathrm{Rb}-\mathrm{Sr}$ data can be
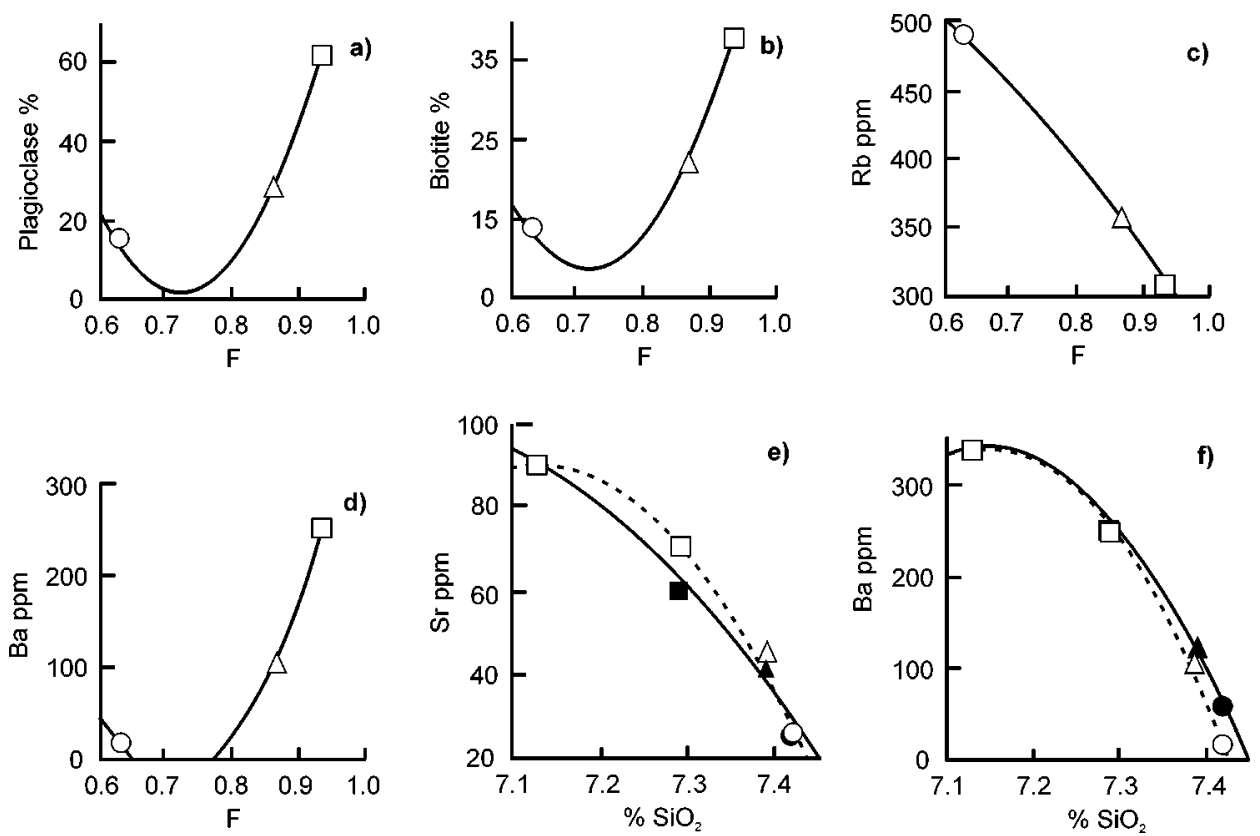

Fig. 11. a-d. Plot of modal plagioclase and biotite of cumulate and of calculated trace element contents in tin-bearing granites from Ervedosa versus the weight fraction of melt $(\mathrm{F})$ remaining during fractional crystallization; e-f. Variation diagrams of $\mathrm{Sr}$ and $\mathrm{Ba}$ contents of these granites compared to results from modelling studies. Symbols as in Fig. 3; open symbols and broken line for analytical data; and closed symbols and solid line for calculated data.

Table 9. Mineral/melt partition coefficients (K) used for granitic melt.

\begin{tabular}{|c|c|c|c|}
\hline & Plagioclase & K-feldspar & Biotite \\
\hline $\mathrm{Sr}$ & 14.7 a) & 12 & $0.04 \mathrm{~d})$ \\
\hline $\mathrm{Ba}$ & 1.65 a) & 22.74 c) & $14.4 \mathrm{~d})$ \\
\hline $\mathrm{Rb}$ & $0.09 \mathrm{~b})$ & $0.94 \quad c)$ & 2 d) \\
\hline
\end{tabular}

a) Blundy \& Wood (1991), b) Nash \& Crecraft (1985), c) and d) Icenhower \& London (1995). 
reset by weak deformation; if the emplacement of granite magmas was syntectonic, the whole-rock ages can be reliable in weakly deformed granites (Page and Bell 1986). So the age of $327 \pm 9 \mathrm{Ma}$ is interpreted as an emplacement age, contemporaneous with shear zone movements. The initial ratio ${ }^{87} \mathrm{Sr} /{ }^{86} \mathrm{Sr}$ calculated for all samples of granites M1, M2 and $\mathrm{M} 3$, used to define the whole-rock Rb-Sr isochron for the age of 327 Ma yielded (Fig. 5b), have an average value of 0.7152 , which is similar to that $(0.7155 \pm 0.0018)$ given by the $\mathrm{Rb}$ $\mathrm{Sr}$ isochron; this confirms that these granites are cogenetic and assimilation of country rock did not occur simultaneously with in situ fractional crystallization.

As the granite $\mathrm{M} 1$ is peraluminous with $\mathrm{A} / \mathrm{CNK}$ values $1.10-1.25$, it was derived from a peraluminous source. Furthermore, it was originated by partial fusion of metasedimentary materials because this granite has a LREE-enriched chondrite normalized pattern and a negative Eu anomaly (Nabelek and Glascock 1995). Its initial ${ }^{87} \mathrm{Sr} /{ }^{86} \mathrm{Sr}$ ratio of $0.7151 \pm$ 0.0015 (Fig. 5a) and $\varepsilon \mathrm{Nd}_{\mathrm{T}}$ of -4.9 confirm that it was derived from a crustal metasedimentary protolith. Castro et al. (1999) did experimental tests on Hercynian granites petrogenesis and concluded that the relationships displayed by Iberian leucogranites indicate that they have been generated from a pure crustal protolith but the source material could have been greywackes or gneisses.

\section{Sn content of granites and its origin}

The average Sn content of granites from Ervedosa ranges from 29 to $72 \mathrm{ppm}$ (Table 2). Sn content increases from muscovite-biotite granite M1 to muscovite granite M3, reaching 99 ppm in some samples of M3 (Fig. 3). So they are Sn-bearing granites (Neiva 1984; Lehmann 1990).

The occurrence of cassiterite as a primary, magmatic mineral, in muscovite granite M3 indicates that the late-stage granite magma was strongly enriched in tin (Haapala 1997). Magmatic cassiterite can crystallize in highly evolved systems because tin is partitioned in favour of granitic melts in deeper granitic intrusions with low chlorine contents (Linnen 1998). The occurrence of carbonaceous pelitic metasediments favours the reduced nature to play a key role in the remobilization of tin (Linnen 1998). Decrease in temperature, salinity, $\mathrm{H}^{+}$activity as well as an increase in oxygen fugacity reduce the solubility of tin (Schwartz et al. 1995).

The textures of granites from Ervedosa are consistent with a dominantly magmatic origin. The muscovite granite M3 has magmatic albite and muscovite and is a late differentiate of the anatectic granite melt M1. The granite M3 is cut by stanniferous quartz veins.

Sn contents of granites, muscovite and biotite increase with the degree of fractionation (Figs. 3, 6, 7), which is confirmed in the linear $\log \mathrm{Sn}-\log \mathrm{TiO}_{2}$ and $\log \mathrm{Sn}-\log \mathrm{Rb} / \mathrm{Sr}$ correlations (Fig. 12). The fractionation suite is traced back to $5 \mathrm{ppm} \mathrm{Sn}$ in the leastevolved portion. Lehmann (1982), in similar conditions, concludes that the source material was not enriched in tin beyond average crustal levels.

Biotite holds an average of $19 \%$ (in M1) and 16\% (in M2), while primary muscovite retains a mean of $21 \%$ (in M1), $57 \%$ (in M2) and $75 \%$ (in M3) of the total granite Sn. So the percentage of total granite $\mathrm{Sn}$ retained in biotite decreases, while that retained in muscovite increases with the increase in the degree of differentiation.

In every granite studied, muscovite retains a higher percentage of total granite Sn (up to 99\% in M3) than biotite does because the modal \% of muscovite is higher than that of 

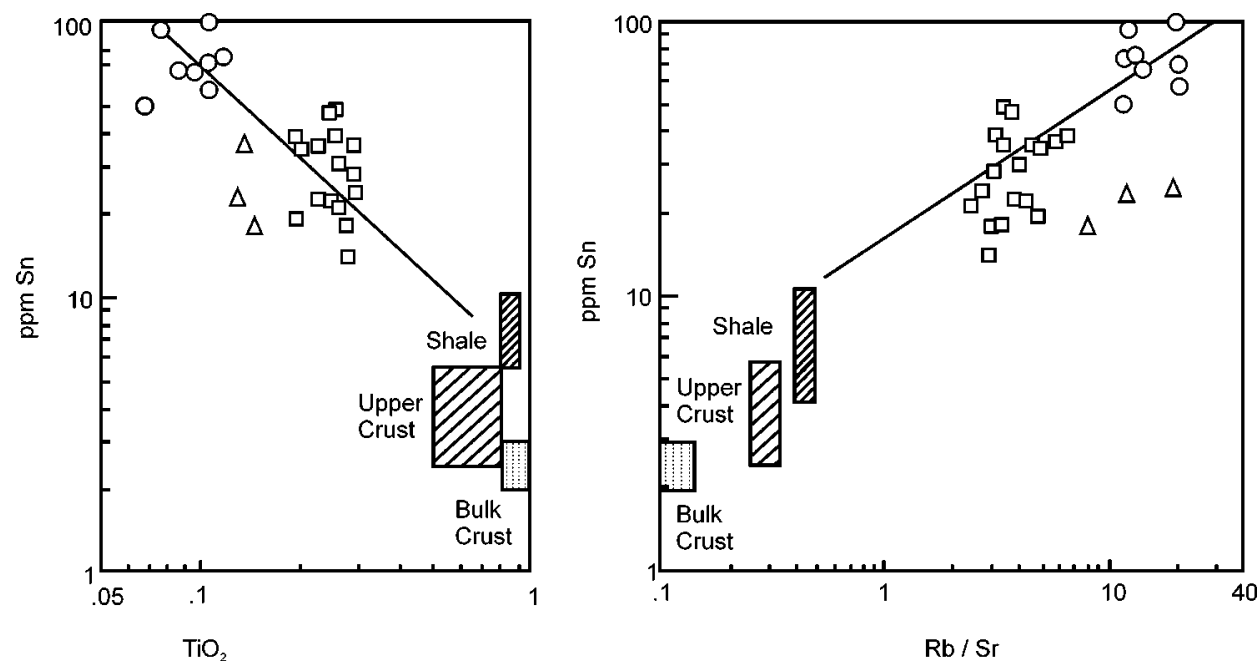

Fig. 12. Correlations: a. $\log \mathrm{TiO}_{2}-\log \mathrm{Sn}$, b. $\log \mathrm{Rb} / \mathrm{Sr}-\log \mathrm{Sn}$. Global reference fields from Lehmann (1990). Symbols as in Fig. 3.

biotite (Table 1), although Sn content of muscovite is lower than that of coexisting biotite (Table 5). Very rare magmatic cassiterite was found in muscovite granite M3. However, in the tin-bearing quartz veins, which cut the country rock and muscovite granite M3, cassiterite is the main concentrator of $\mathrm{Sn}$.

\section{Conclusions}

a) The granites from Ervedosa have many characteristics of S-type granite (Chappell and White 1974 and 1992) and $\mathrm{C}_{\mathrm{ST}}$ granite (Barbarin 1990).

b) The highly peraluminous tin-bearing granites from Ervedosa (muscovite-biotite granites M1 and M2 and muscovite granite M3 show trends of fractionation for major and trace elements of rocks and define a whole-rock $\mathrm{Rb}-\mathrm{Sr}$ isochron of $327 \pm 9 \mathrm{Ma}$. There is decrease in $\Sigma$ REE and increase in the negative Eu anomaly from the oldest granite M1 to the youngest granite M3.

c) Biotite and muscovite show trends of fractionation for major and trace elements. Generally trace elements are more concentrated in biotite than in the coexisting muscovite.

d) Equilibrium may have occured for $\mathrm{Li}, \mathrm{Nb}, \mathrm{Sn}, \mathrm{Rb}, \mathrm{Li} / \mathrm{Mg}$ and $\mathrm{K} / \mathrm{Rb}$ between coexisting micas, probably after crystallization.

e) The muscovite-biotite granite M2 and muscovite granite M3 are the product of in situ fractional crystallization of the muscovite-biotite granite M1 controlled by separation of plagioclase, K-feldspar, biotite and quartz. 
f) The initial ${ }^{87} \mathrm{Sr} /{ }^{86} \mathrm{Sr}$ ratio $0.7151 \pm 0.0015$ and $\varepsilon \mathrm{Nd}_{\mathrm{T}}=-4.9$ suggest that the muscovite-biotite granite $\mathrm{M} 1$ results from partial melting of metasedimentary materials.

g) In granites, biotite and muscovite, the Sn contents increase with magmatic differentiation. Primary muscovite retains a higher percentage of the total granite Sn than biotite. This effect increases with magmatic fractionation.

h) The muscovite granite M3 has very rare magmatic cassiterite, indicating that the granite magma was enriched in tin.

i) The melt temperatures range from $765^{\circ} \mathrm{C}$ for granite $\mathrm{M} 1$ to $735^{\circ} \mathrm{C}$ for granite $\mathrm{M} 3$ and $\mathrm{P}_{\mathrm{H}_{2} \mathrm{O}}$ ranges from 4 to $3 \mathrm{~kb}$. $\mathrm{F}$ content in melt increases during magmatic differentiation. Reequilibration of feldspars occured at $567-329^{\circ} \mathrm{C}$.

\section{Acknowledgements}

Thanks are due to Dr. J. Esson for the XRF and microprobe facilities in the Department of Earth Sciences, University of Manchester, U.K.; Dr. S. J. Parry for the use of laboratory facilities to determine REE in the Imperial College Reactor Center, Ascot, U.K.; Prof. S. Moorbath, Dr. M. J. Whitehouse and Mr. R. Goodwin, Department of Earth Sciences, University of Oxford, U.K., for the isotopic data. We are grateful to Prof. B. J. Wood and to Dr. Ben Williamson for the EUGFBristol facility, contract ERBFMGECT980128, to use its electron microprobe to analyze accessory minerals, at the Department of Earth Sciences, University of Bristol, U.K.. Funding was provided by a grant from INIC and another, from Gulbenkian, Portugal, for M. E. P. Gomes. This research was carried out under the programme of the Geosciences Centre, University of Coimbra, Portugal.

\section{References}

Abdel-Rahman AM (1994) Nature of biotites from alkaline, calk-alkaline, and peraluminous magmas. J Petrol 35, 525-541

Albuquerque CAR (1975) Partition of trace elements in coexisting biotite, muscovite and potassium feldspar of granitic rocks, northern Portugal. Chem Geol 16, 89-108

Barbarin B (1990) Granitoids: main petrogenetic classifications in relation to origin and tectonic setting. Geological J 25, 227-238

Bea F (1996) Residence of REE, Y, Th and U in granites and crustal protoliths; implications for the chemistry of crustal melts. J Petrol 37, 521-552

Blundy JD, Wood BJ (1991) Crystal-chemical controls on the partitioning of Sr and Ba between plagioclase feldspar, silicate melts, and hydrothermal solutions. Geochim Cosmochim Acta 58, 2609-2627

Brown GC, Hughes DJ, Esson J (1973) New X.R.F. data retrieval techniques and their application to U.S.G.S. standard rocks. Chem Geol 11, 223-229

Burkhard DJM (1991) Temperature and redox path of biotite-bearing intrusives: a method of estimation applied to S- and I-type granites from Australia. Earth Planet Sci Lett 104, 89-98

Butler BCM (1967) Chemical study of minerals from the Moine schists of the Ardnamurchan area, Argyllshire, Scotland. J Petrol 8, 233-267

Candela PA (1997) A review of shallow, ore-related granites: textures, volatiles, and ore metals. J Petrol 38 , 1619-1633

Casminex-prospecções mineiras, lda (1982) Unpublished technical report, 9 pp

Castro A, Patiño Douce AE, Corretgé LG, de la Rosa JD, El-Biad M, El-Hmidi H (1999) Origin of peraluminous granites and granodiorites, Iberian massif, Spain: an experimental test of granite petrogenesis. Contrib Mineral Petrol 35, 255-276

Chappell BW, White AJR (1974) Two contrasting granite types. Pacific Geol 8, 173-174

Chappell BW, White AJR (1992) I- and S- type granites in the Lachlan Fold Belt. Trans R Soc Edinburgh: Earth Sci 83, 1-26 
Elkins LT, Grove TL (1990) Ternary feldspar experiments and thermodynamic models. Amer Mineral $\mathbf{7 5}$, 544-559

Foster MD (1960) Interpretation of the composition of trioctahedral micas. US Geol Surv Prof Paper 354-B, $1-49$

Föster H-J (1998) The chemical composition of REE-Y-Th-U-rich accessory minerals in peraluminous granites of the Erzgebirge-Fichtelgebirge region, Germany, Part I: The monazite-(Ce)-brabantite solid solution series. Amer Mineral 83, 259-272

Godinho MM, Silva FG (1974) Lítio em granitóides da região de Guardão (Caramulo, Portugal). Mem Not, Publ Mus Lab Geol, Univ Coimbra 78, 79-104

Gokhale NW (1968) Chemical composition of biotites as a guide to ascertain the origin of granites. Bull Geol Soc Finland 40, 107-111

Gomes MEP (1996) Mineralogia, petrologia e geoquímica das rochas granitóides da área de Rebordelo-BouçaTorre de D. Chama Agrochão e as mineralizações associadas. Unpublished Ph. D. thesis, Universidade de Trás-os-Montes e Alto Douro, $323 \mathrm{pp}$

Guidotti CV, Cheney JT, Guggenheim S (1977) Distribution of titanium between coexisting muscovite and biotite in pelitic schists from nothwestern Maine. Amer Mineral 62, 438-448

Haapala I (1997) Magmatic and postmagmatic processes in tin-mineralized granites: topaz-bearing leucogranite in the Eurajoki rapakivi granite stock, Finland. J of Petrol 38, 1645-1659

Icenhower JP, London D (1995) An experimental study of element partitioning between biotite, muscovite and coexisting peraluminous granitic melt at $200 \mathrm{MPa}\left(\mathrm{H}_{2} \mathrm{O}\right)$. Amer Mineral 80, 1229-1251

Icenhower JP, London D (1997) Partitioning of fluorine and chlorine between biotite and granitic melt: experimental calibration at $200 \mathrm{MPa}\left(\mathrm{H}_{2} \mathrm{O}\right)$. Contrib Mineral Petrol 127, 17-29

Le Bas MJ, Streckeisen (1991) The IUGS systematics of igneous rocks. J Geol Soc London 148, 825-833

Lécolle M, Derré C, Noronha F, Roger G (1981) Distribution des concentrations Sn-W dans le Nord du Trásos-Montes (Portugal); typologies gitologiques et mineralógiques. In: Raport final-ATP du CNRS "Formation et distribution des gisements-1978”, décision d'aide n $3548,19 \mathrm{pp}$

Lehmann B (1982) Metallogeny of tin: magmatic differentiation versus geochemical heritage. Econ Geol 77, 50-59

Lehmann B (1990) Metallogeny of tin. Lecture notes in earth sciences, 32. Berlin: Springer-Verlag, $211 \mathrm{pp}$

Linnen RL (1998) Depth of emplacement, fluid provenance and metallogeny in granitic terranes: a comparison of western Thailand with other tin belts. Min Deposita 33, 461-476

Ludwig KP (1990) Isoplot: A plotting and regression program for radiogenic-isotope data, for IBM-PC compatible computers. U S Geological Survey Open File Repport 85, p 513

Miller CF, Stoddard EF, Bradfish LJ, Dollase WA (1981) Composition of plutonic muscovite: genetic implications. Can Mineral 19, 25-34

Mittlefehldt DW, Miller CF (1983) Geochemistry of structures Wash Pluton, California: implications for "anomalous" trace element behaviour during differentiation of felsic magmas. Geochim Cosmochim Acta 47, 109-124

Monier G, Mergoil-Daniel J, Labernardière H (1984) Générations sucessives de muscovites et feldspaths potassiques dans les leucogranites du massif de Millevaches (Massif Central français). Bull Minéral 107, $55-68$

Montel J-M (1993) A model for monazite/melt equilibrium and application to the generation of granitic magmas. Chem Geol 110, 127-146

Nachit H, Razafimahefa N, Stussi JM, Carron JP (1995) Composition chimique des biotites et typologie magmatique des granitoides. C R Acad Sci Paris 301, 11, 813-818

Nash WP, Crecraft HR (1985) Partition coefficients of trace elements in silicic magmas. Geochim Cosmochim Acta 49, 2309-2322

Neiva AMR (1977) Distribution of some elements between coexisting minerals from granites and pegmatites from central northern Portugal. Chem Geol 20, 223-233

Neiva AMR (1984) Geochemistry of tin-bearing granitic rocks. Chem Geol 43, 241-256

Nabelek P, Glascock MD (1995) REE-depleted leucogranites, Black Hills, South Dakota: a consequence of disequilibrium melting of monazite bearing schists. J Petrol 36, 1055-1071

Neves LJPF (1997) Trace element content and partitioning between biotite and muscovite of granitic rocks: a study in the Viseu region (Central Portugal). Eur J Mineral 9, 849-857

Nockolds SR (1947) The relation between chemical composition and paragenesis in the biotite micas of igneous rocks. Am J Sci 245, 401-420

Page RW, Bell TH (1986) Isotopic and structural responses of granite to successive deformation and metamorphism. J Geol 94, 365-379 
Pankhurst RJ, O’Nions RK (1973) Determination of Rb-Sr and ${ }^{87} \mathrm{Sr} /{ }^{86} \mathrm{Sr}$ ratios of some standard rocks and evaluation of X-ray fluorescence spectrometry in Rb-Sr geochemistry. Chem Geol 12, 127-136

Pichavant M (1997) Genesis of granite-related tin mineralizations: the importance of magmatic processes. In: Ferreira VP and Sial AN (eds) Extended abstracts and programme of the Second International Symposium on granites and associated mineralizations, Salvador, Brazil, 14-18 August 1997, pp 78-79

Pinto MS, Casquet C, Ibarrola E, Corrétge LG, Ferreira MP (1987) Síntese geocronológica dos granitoides do Maciço Hesperico. In: Bea F, Carmina A, Gonzalo JC, Plaza ML, Rodrigues JML (eds) Geologia de los granitoids y rocas associadas del Macizo Hespérico, Libro Homenage a L. C. G. Figueirola. Editorial Rueda, Madrid, 69-86

Ribeiro A (1974) Contribution à l'étude tectonique de Trás-os-Montes Oriental. Mem Serv Geol Portugal 24, $168 \mathrm{pp}$

Ribeiro A, Quesada C, Dallmeyer RD (1990) Geodynamic evolution of the Iberian Massif. In: Dallmeyer RD, Martinez Garcia (eds) Pré-Mesozoic Geology of Iberia, Springer-Verlag, Berlin Heidelberg, 399-409

Schwartz MO, Rajah SS, Askury AK, Putthapiban P, Djaswadi S (1995) The Southeast Asian Tin Belt. Earth Sci Rev 38, 95-293

Watson EB, Harrison TM (1983) Zircon saturation revisited: temperature and composition effects in a variety of crustal magma types. Earth Planet Sci Lett 64, 295-304

Wark DA, Miller CF (1993) Accessory mineral behaviour during differentiation of a granite suite: monazite, xenotime and zircon in the Sweetwater Wash pluton, southeastern California, U.S.A. Chem Geol 110, 49-67 